\title{
Systemic Banking Crises, Financial Liberalization and Governance
}

\author{
Basma Majerbi* \\ University of Victoria, Canada \\ Houssem Rachdi \\ University of Jendouba, Tunisia
}

This paper revisits the relationship between liberalization and systemic banking crisis in light of a more comprehensive measure of financial liberalization and its interaction with various measures of banking governance and institutional quality. We estimate the probability of systemic banking crisis for a sample of 53 countries using multivariate logit models and allowing the determinants of crisis to vary across country groups. The results show that liberalization increases the likelihood of crisis only at early stages of financial reforms and up to certain level, after which, greater liberalization, through more advanced financial reforms, tends to reduce the probability of systemic banking crisis. We also find that stricter banking regulation and supervision, better law and order, government stability, lack of corruption and bureaucratic efficiency generally lead to reduced probability of crisis. However, the magnitude and significance of the beneficial effects of governance largely depend on the degree of liberalization and vary across countries depending on their levels of income and development. (JEL: E44, F36, G15, G18, G21, G28)

Keywords: systemic banking crises; early warning systems; multivariate logistic regressions; financial liberalization; institutional quality and banking governance

\footnotetext{
* Corresponding author: majerbi@uvic.ca. Gustavson School of Business, University of Victoria, PO Box 1700 STN CSC Victoria BC, V8W 2Y2, Canada.

The authors would like to thank Marc Quintyn, Paul Schure, Iftekhar Hasan, Javier Reyes, Po-Hsin Tseng, an anonymous referee, and participants at the INFINITI conference and Multinational Finance Society Annual Conference for valuable comments. Majerbi acknowledges financial support from the Social Sciences and Humanities Research Council of Canada (SSHRC).
}

(Multinational Finance Journal, 2014, vol. 18, no. 3/4, pp. 281-336)

(C) Multinational Finance Society, a nonprofit corporation. All rights reserved. DOI: $10.17578 / 18-3 / 4-4$ 


\section{Introduction}

The banking sector plays an important role in fostering economic development and growth, and governments around the world pay close attention to insure the well-functioning and stability of their banking sectors. Indeed, a banking crisis is often very costly to an economy and its negative impact on the real sector can have lasting effects. A study by Laeven and Valencia (2008) looked at 124 systemic banking crises over the period 1970 to 2007 . They estimate the fiscal costs of a systemic banking crisis at about 13 percent of GDP on average, and it can be as high as 55 percent of GDP. In addition, the study shows that output losses of systemic banking crises can be substantial, averaging about 20 percent of GDP during the first four years of the crisis.

Therefore, predicting the occurrence of banking crises has received great attention from both academic researchers and policy makers. In particular, there is extensive literature on early warning systems (EWSs) for systemic banking crises. These predictive models try to use various indicators (signals) to estimate the probability of occurrence of a systemic banking crisis. ${ }^{1}$ The attractiveness of these models stems from the desire of researchers and practitioners to find ways to predict the occurrence of a banking crisis as early as possible so that governments can take the necessary measures to prevent the crisis, or at least be prepared to minimize its negative effects through early and timely policy actions.

This paper contributes to the literature on systemic banking crises by focusing more specifically on the role of financial liberalization and its interaction with the institutional and governance environment in which the banking sector operates. Many previous studies point to financial liberalization as one of the main causes of crises, especially in developing and emerging countries (Caprio and Klingebiel 1996; Kaminsky and Reinhart, 1999). For instance Kaminsky and Reinhart (1999) note that banking crises increased dramatically in the post-liberalization period of the 1980s and 1990s. A number of subsequent studies using various models and datasets reach similar conclusions suggesting that financial liberalization increases the likelihood of banking crises. This view stands in contrast to the

1. Note that EWS models do not offer precise predictions for the occurrence of a crisis but rather allow us to identify periods of heightened risk or increased vulnerability of the banking sector. 
financial liberalization literature, which highlights the positive impact of liberalization on financial sector development and economic growth (see, e.g., Tornell et al. 2004; Bekaert et al. 2005). ${ }^{2}$

Previous research also looked at the role of institutional and governance factors as separate determinants of banking crises. However, it is likely that these institutional factors can also influence the likelihood of crisis through their interaction with liberalization. Thus our study revisits the link between financial liberalization and systemic banking crisis in an EWS framework by more specifically investigating whether this link is affected by or depends on the institutional characteristics of the country and other measures of governance affecting the banking sector. The measures used in this study are: banking regulation and supervision, law and order, (lack of) corruption, deposit insurance, bureaucratic efficiency and government stability.

We contribute to crisis literature in several ways. First, we use the most recent measure of financial liberalization proposed by Abiad et al. (2008), the Financial Reform Index. This measure is more comprehensive and presents several advantages over other liberalization measures used in previous studies of banking crises as explained below. More importantly, this measure, through its more detailed grading scale, allows us to estimate the impact of various governance measures at different levels of liberalization, thus accounting for cross-country variations over the multiple dimensions of financial liberalization over time rather than just limiting the comparison between fully repressed and fully liberalized states.

Another key contribution of our paper is that it uses a model estimation approach that allows for the determinants of crisis to vary depending on different country groupings. As noted in a recent paper by Barrel et al. (2010), most previous studies of systemic banking crisis prediction via EWSs rely on a common set of explanatory variables even though they include cross-sections of heterogeneous economies. In this study, we use country groupings that include more homogeneous economies in each panel logit regression. This allows us to identify, for each class of economies, the most significant control variables or signals likely to improve the design of the EWS for systemic banking

2. Tornell et al. (2004) find that financial liberalization does indeed lead to crisis, but also show theoretically and empirically that despite the higher incidence of crises, financial liberalization leads to more rapid growth in countries with severe credit market imperfections. 
crises. ${ }^{3}$ Finally, our study includes a discussion of the marginal effects of governance and institutional measures on the predicted probability of crisis at different levels of liberalization as illustrated by the various figures presented in this paper.

Our results can be summarized as follows: Using the Financial Reform Index of Abiad et al. (2008), we document an inverted U-shaped relationship between liberalization and systemic banking crisis that is robust to the country sample and the choice of control variables included in the logistic regressions. This is consistent with some recent evidence suggesting that liberalization increases the likelihood of crisis in the short run, or at initial stages of liberalization, after which, increased liberalization leads to lower probability of crisis. More specifically, we show that the turning point at which liberalization starts to have a negative relationship with the likelihood of crisis, varies depending on the type of economy (high income-OECD versus Emerging/Developing countries) ${ }^{4}$ Further, more interesting and novel findings are revealed when we study this non-linear relationship between crisis and liberalization conditional on the countries institutional environment and the quality of the banking sector governance. While there is evidence that, overall at the global sample, improved measures on most governance dimensions, are associated with lower probability of crisis, this beneficial governance effect operates differently for different types of economies and seems to vary depending on where the country is situated on the liberalization process.

The rest of the paper is organized as follows. In section II we review the theoretical and empirical literature explaining the link between liberalization, systemic banking crises and the governance and institutional environment. Section III presents the model and data. In section IV, we present the main results and some robustness checks. Finally, section V concludes the paper and suggests avenues for future research.

3. As explained by Barrell et al (2010), the triggers of a crisis depend on the type of economy and the nature of its banking system. For example, in advanced economies with high levels of banking intermediation and developed financial markets, shocks to terms of trade are less important than other factors such as real estate or asset price bubbles.

4. Note that we do not estimate empirically these turning points in the relationship between liberalization and crisis. Rather, we reach this conclusion based on an examination of the various plots of the predicted probability of crisis based on the model's estimated coefficients. 


\section{Financial Liberalization, Banking Crises and Governance}

\section{A. Financial liberalization and banking crises}

There is extensive theoretical and empirical literature studying the link between banking crises and financial liberalization. This link was previously noted in an early paper by Diaz-Alejandro (1985) about the Chilean crisis of 1981-83 following the removal of foreign capital inflow restrictions in 1981. Theoretical models explaining this link often attribute the potential negative impact of liberalization to increased competition and moral hazard from promised bailouts that follow the transition from financial repression to financial liberalization (Hellman et al. (2000), Dekle and Kletzer (2001)). The main idea behind this argument is that financial liberalization, through the elimination of interest rate ceilings and credit controls, reduces bank profitability because of increased competition. This reduction in profitability increases the moral hazard problem by lowering the incentives for banks to make good loans, therefore resulting in a more fragile domestic banking sector. Daniel and Jones (2006) offer an alternative explanation. They develop a dynamic general-equilibrium model in which they model the evolution of a newly liberalized bank's opportunities and incentives to take on risk over time in a small open economy. Their model suggests that even in the presence of a well-designed banking system with good long-run properties, many emerging countries will first enjoy an initial period of rapid growth immediately after liberalization and then enter a period of heightened risks of banking crisis. They conclude that in addition to the competition and moral hazard problems, financial liberalization in itself is a major contributing factor that increases the likelihood of a banking crisis.

Giannetti (2007) develops a theoretical model relating banking crises in emerging markets to financial liberalization by looking more specifically at the impact of the liberalization of capital inflows. Her model also shows that immediately after the financial liberalization, emerging economies enjoy low interest rates and experience lending and investment booms. This transition period is followed by an abrupt and sudden reversal of capital flows. Noy (2004) develops and tests two hypotheses to explain the increased likelihood of a systemic banking crisis after financial liberalization: the 'monopoly power' and the 'lax 
supervision' hypotheses. The first one is based on the increased competition argument similar to what has been proposed in previous studies. The liberalization of domestic interest rates typically results in increased deposits rates offered by domestic banks, especially after the entry of more competitive foreign banks. As competition intensifies and banks profit margins decrease, weak and inefficient institutions will go bankrupt and the newly liberalized country is more likely to experience a systemic banking crisis. In the second hypothesis, Noy (2004) makes the proposition that financial liberalization motivates and enables excessive risk-taking behavior by banks only if it is accompanied by inefficient supervision. Thus, in the absence of an efficient supervisory structure, financial liberalization is more likely to have adverse effects on the stability of the banking sector.

Eichengreen and Arteta (2002) provides a survey of empirical studies that provide strong evidence supporting the hypothesis that financial liberalization increases the likelihood of systemic banking crises, such as the studies by Caprio and Klingebiel (1996), Demirgón-Kunt and Detragiache (1998), Kaminsky and Reinhart (1999) and Glick and Hutchison (2001). ${ }^{5}$ For instance, in the Kaminsky and Reinhart (1999) sample of 20 countries, over $70 \%$ of banking crises were preceded by financial liberalization within the last 5 years and the probability of banking crisis conditional on financial liberalization having occurred is higher than the unconditional probability of banking crisis. A widely cited study by Demirgón-Kunt and Detragiache (1998) finds that financial liberalization increases the risk of banking crises within a few years of the liberalization process. It is worth noting, however, that their study focuses on domestic liberalization (measured by a dummy variable that takes 1 in the first year of interest rates decontrols). A similar result showing an increased likelihood of banking crisis after domestic liberalization is shown by Weller (2001). Many other studies using various liberalization indicators (internal and/or external) and different methodologies provide further evidence that financial liberalization significantly contributes to increasing the risk of banking crises (Barth et al. (2004), Ranciere et al. (2006), Aka (2006), Gupta and Karapatakis (2008), Kaminsky and Schmukler (2008) among others). As will be discussed later in this paper, there are a number of

5. Note that Kaminsky and Reinhart (1999) and Glick and Hutchison (2001) looked at both currency and banking crises (twin crises). They found that while currency crises can be predicted by banking crises, financial liberalization remains the most powerful single predictor of banking sector crises. 
shortcomings to these studies particularly related to the measure of financial liberalization. We attempt to address this by using a more comprehensive liberalization measure (the Financial Reform Index of Abiad et al. (2008) which captures many dimensions of financial reform that gradually lead to a greater liberalization of the financial system as a whole. Our study also allows for a nonlinear relationship between liberalization and the likelihood of crisis and makes it possible to evaluate the predicted probability of crisis at different intermediate levels (or degrees) of liberalization rather than simply dividing countries between either fully repressed or fully liberalized.

\section{$B$. The effects of governance and institutional quality on banking crises}

Previous literature suggests that the negative effect of financial liberalization on banking crises may be exacerbated in the presence of poor institutional environment and weak governance. Intuitively, we may expect better governance of banking institutions to reduce the probability of occurrence (or the severity) of a banking crisis by reducing the moral hazard problem following financial liberalization. A number of studies looked at the impact of banking governance, particularly prudential regulation and supervision, with mixed empirical findings. For instance, Angkinand (2009) uses a panel of 35 countries to analyze the relationship between banking regulation and supervision, and the severity of banking crises. The results of this study suggest that countries that provide comprehensive deposit insurance coverage and enforce strict bank capital adequacy requirements experience smaller output costs of crises. However, the author does not find evidence of a significant impact of bank supervision. Arnone et al. (2007) study looks at the relationship between the quality of banking supervision and aspects of governance of the banking supervisors. They find a positive correlation between the transparency of the supervisor and the effectiveness of banking supervision.

It is not clear, however, whether better banking supervision can help ensure better stability of the financial system or help contain a systemic risk. Some studies tried to investigate the effect of bank capital regulation and supervision on banks' risk taking. For instance Barth et al. (2004) and Angkinand et al. (2006) find that bank capital adequacy limits banks' risk taking. However, both studies find that bank supervision does not have a significant impact on banks, risk-taking and the probability of banking crisis. Other studies, such as Beck et al. 
(2006) find that particular types of banking regulation and supervision can have a stronger impact on the level of risk taking by banks.

While a number of studies focus on the role of banking regulation and supervision as well as the institutional environment more generally as separate explanatory factors for the occurrence of banking crises, there is limited research that looks more specifically at the interaction effects between liberalization and institutional and governance variables. Mehrez and Kaufmann (2000) develop a theoretical model that links transparency to the probability of a financial crisis. Using data from 56 countries, they find the lack of transparency increases the probability of financial crises after financial liberalization. They use several proxies for "transparency" including the corruption index from ICRG, and other measures constructed by combining other available data and surveys. Demirgúç-Kunt and Detragiache (1998) model incorporates the interaction effect between domestic liberalization and several institutional variables such as law and order, contract enforcement, bureaucracy, and corruption. Noy (2004)'s study also considers the interaction between domestic financial liberalization and supervision (proxied by three different measures, including the degree of corruption) and concludes that over longer horizons (3-5 years) banking crises occur as a result of weak supervision after liberalization. Currie (2006) proposes a new theory of financial regulation suggesting that countries should strengthen their capacity to conduct effective prudential supervision, before attempting to implement liberalization policies.

A more recent study by Angkinand et al. (2010) looks at the interaction of liberalization with capital regulation and supervision, in addition to controlling for explicit deposit insurance coverage ${ }^{6}$. Using a sample of 48 countries, they document an inverted U-shaped relationship between liberalization and the likelihood of crisis. In particular, their results indicate that tighter capital regulation and supervision allows countries to benefit more from liberalization and to achieve a steeper reduction in crisis probability.

Our study extends this literature by looking at the interaction effects of financial liberalization with a more comprehensive set of variables that capture both the general institutional environment of the country

6. As a robustness check, the authors also use the rule of law and lack of corruption as independent controls to proxy for the general institutional quality in the country (legal and political systems), but none of these measures is examined in terms of its interaction with financial liberalization. 
and the governance of the banking sector. In particular, we are interested in measuring the marginal effects of these additional variables on the predicted probability of crisis at different levels of liberalization. Further, by using different country groupings, we attempt to determine if these effects behave differently across various types of economies characterized by different levels of banking governance and institutional quality. A more detailed description of the variables used is given in section III.C below.

\section{Empirical model and data}

\section{A. The model}

The literature on Early Warning Systems (EWSs) for systemic banking crises offers a range of estimation techniques, which include the multivariate logit approach used in Demirgúc-Kunt and Detragiache (1998) and the signal extraction approach used in Kaminsky and Reinhart (1999). ${ }^{7}$ More recently, Karim (2008) among others, uses a binary recursive trees approach to predicting crises. Davis and Karim (2008) compare various EWS models and show that the logit model outperforms the signal extraction model for global EWSs (including many countries) while the signal extraction approach is more successful at predicting crises at the country-specific level. Since we are interested in a multi-country estimation, we use the logit model to examine the impact of financial liberalization and its interaction effects with institutional/governance factors on the probability of systemic banking crisis. The multivariate logit approach relates the likelihood of occurrence or non-occurrence of a crisis to a vector of explanatory variables. The probability that the systemic banking crisis dummy takes a value of one (crisis occurs) at a given point in time is computed by the value of the logistic cumulative distribution function evaluated for the data and the estimated parameters at that point in time. This model is specified as follows:

$$
Y_{i, t}=\operatorname{CRISIS}_{i, t}=\beta X_{i, t-1}+\varepsilon_{i t}
$$

Where the dependent variable $Y_{i, t}$ is the crisis dummy for country $i$ at

7. Other studies used multivariate probit models to estimate the probability of a banking crisis, such as Eichengreen and Rose (1998) and Glick and Hutchison (2001). 
time $t$. It takes a value of one when the country is experiencing a systemic banking crisis, and zero otherwise. $X_{i, t-1}$ is a vector of lagged explanatory variables and $\beta$ is a vector of unknown coefficients associated with the explanatory variables. We use lagged explanatory variables to reduce the endogeneity problem. Let $P_{i t}$ denote the probability that a banking crisis will occur in country $i$ at period $t ; P_{i t}$ is given by the cumulative logistic distribution function $F$ of the explanatory variables:

$$
P_{i t}=\operatorname{Pr} o b\left(Y_{i, t}=1\right)=F\left(\beta X_{i, t-1}\right)=\frac{e^{\beta^{\prime} X_{i, t-1}}}{1+e^{\beta^{\prime} X_{i, t-1}}}
$$

The vector of unknown coefficients $\beta$ is estimated by maximizing the following log-likelihood function:

$$
\begin{array}{r}
\log _{e} L=\sum_{i=1}^{N} \sum_{t=1}^{T}\left[\left(Y_{i t} \log _{e} F\left(\beta^{\prime} X_{i, t-1}\right)\right)+\right. \\
\left.\left(1 Y_{i, t}\right) \log _{e}\left(1 F\left(\beta^{\prime} X_{i, t-1}\right)\right)\right]
\end{array}
$$

In this logistic framework, the signs of the estimated parameters can easily be interpreted as either increasing or decreasing the probability of a crisis. However, the interpretation of the magnitude of the effect of a specific explanatory variable on the crisis probability is less straightforward because it is conditional on the values of all other variables in the vector $X^{8}$

\section{B. The empirical methodology}

In the first stage of our empirical procedure, we estimate the model

8. Further, as explained by Davis and Karim (2008), the parameters obtained by maximizing equation (3) above do not represent constant marginal effects of $X_{i}$ on the crisis probability. Rather, the marginal effect of $X_{i}$ on the crisis at time $t$ is given by $P_{i t}^{*}\left(1-P_{i t}\right)^{*} \beta_{i}$. Since the probabilities depend on the values of $X_{i t}$, for a given coefficient, a single explanatory variable can have changing marginal contributions to crisis probability depending on its starting level. If the crisis probability is already at an extreme value (low or high), an explanatory variable will make marginally little difference to crisis compared to the case where the crisis probability is around the 0.5 range. In the latter case, a change in the same variable is more likely to trigger a crisis signal if the threshold is at 0.5 . Note that the threshold maybe set at a lower value depending on the user of the EWS model. 
specified in equations (1)-(3) by including standard macroeconomic and financial explanatory variables in the vector $X$ following previous literature on EWSs as described in section III.C below. The first stage logit regressions are done both using the full country sample (naïve model) and using two sub-sets of country groups that represent more or less similar types of economies (regional model). Berg et al. (2008) distinguish between these two approaches and show that the "regional" model is superior to an all-countries "naïve" model because there is less idiosyncratic noise. More recently, Barrell et al. (2010) use EWS models for banking crises with a focus on the role of bank regulation and property prices. They also point out the limitations of using pooled logit regressions that integrate a global sample of heterogeneous countries to identify the most significant crisis indicators. Their study restricts the sample to include only 14 OECD countries, which they argue represent a relatively more homogeneous group of economies. In our study, the "naïve" model is estimated using all available observations from our dataset of 53 countries, but we also estimate a "regional" model by separating the sample into two sub-sets of countries: the first includes 22 high income-OECD countries according to the World Bank classification, and the second includes the remaining 31 countries which we refer to as the "Emerging/Developing countries" group. ${ }^{9}$ The "regional" model estimation approach allows us to identify for each group of countries the set of macroeconomic control variables that are most significant in determining the probability of a systemic banking crisis, which are then used in the main model estimation that includes the effects of financial liberalization in combination with the governance and institutional measures. This approach is superior to simply using country dummies as in some previous crisis models because it allows us to use different explanatory variables for each sample without dropping entire countries because of missing observations.

Our main empirical model for estimation, after identifying the most significant macroeconomic control variables $X_{i}$ for each country group (and for the entire sample), is as follows:

9. Note that although we use the same terminology of "naïve" versus "regional" model proposed by Berg et al. (2008), the use of the word "regional" in our context does not refer to geographical regions, but rather to dividing the global sample into subsets of more or less homogenous economies. 
TABLE 1. Summary Statistics

\begin{tabular}{|c|c|c|c|c|c|}
\hline \multicolumn{6}{|l|}{ A. Global Sample } \\
\hline VARIABLES & Observation & Mean & Std.Dev. & Min & Max \\
\hline Systemic Banking Crises & 1375 & 0.149 & 0.357 & 0 & 1 \\
\hline GDP Growth & 1378 & 1.743 & 3.608 & -16.510 & 15.811 \\
\hline Real interest rate & 1127 & 7.128 & 10.856 & -46.633 & 84.047 \\
\hline Inflation & 1358 & 5.091 & 0.260 & 4.605 & 6.062 \\
\hline Overvaluation & 1338 & 0.090 & 23.980 & -208.298 & 387.266 \\
\hline Current account & 1360 & -1.102 & 4.966 & -18.183 & 24.458 \\
\hline Terms of trade ( $\%$ GDP) & 1372 & 62.800 & 32.512 & 11.545 & 228.875 \\
\hline Private Credit (\%GDP) & 1370 & 58.855 & 43.831 & 3.907 & 232.203 \\
\hline Financial Liberalization Index & 1378 & 11.384 & 5.115 & 0 & 18 \\
\hline Banking supervision & 1378 & 0.978 & 1.014 & 0 & 3 \\
\hline Law and order & 1378 & 3.887 & 1.065 & 0 & 6 \\
\hline Lack of corruption & 1378 & 3.578 & 1.521 & 0 & 6 \\
\hline Deposit insurance & 1378 & 0.849 & 0.358 & 0 & 1 \\
\hline Bureaucratic efficiency & 1378 & 2.630 & 1.148 & 0 & 4 \\
\hline Government stability & 1378 & 7.521 & 2.058 & 1 & 11.083 \\
\hline \multicolumn{6}{|l|}{ B. High-Income OECD Countries } \\
\hline Systemic Banking Crises & 572 & 0.080 & 0.272 & 0 & 1 \\
\hline GDP Growth & 572 & 2.186 & 2.434 & -11.715 & 10.564 \\
\hline Real interest rate & 524 & 5.607 & 4.317 & -5.977 & 50.984 \\
\hline Inflation & 561 & 5.183 & 0.146 & 4.667 & 5.388 \\
\hline Overvaluation & 572 & 0.165 & 32.165 & -208.298 & 387.266 \\
\hline Current account & 571 & -0.137 & 4.366 & -15.323 & 16.746 \\
\hline Terms of trade (\%GDP) & 566 & 66.334 & 30.416 & 16.109 & 184.121 \\
\hline Private Credit (\%GDP) & 568 & 89.228 & 41.536 & 9.011 & 232.203 \\
\hline Financial Liberalization Index & 572 & 14.560 & 3.643 & 2 & 18 \\
\hline Banking supervision & 572 & 1.520 & 1.106 & 0 & 3 \\
\hline Law and order & 572 & 5.388 & 0.892 & 2 & 6 \\
\hline Lack of corruption & 572 & 4.857 & 1.097 & 2 & 6 \\
\hline Deposit insurance & 572 & 0.954 & 0.208 & 0 & 1 \\
\hline Bureaucratic efficiency & 572 & 3.647 & 0.571 & 1.750 & 4 \\
\hline Government stability & 572 & 8.254 & 1.712 & 2 & 11.083 \\
\hline \multicolumn{6}{|c|}{ C. Emerging/Developing Countries } \\
\hline Systemic Banking Crises & 803 & 0.199 & 0.399 & 0 & 1 \\
\hline GDP Growth & 806 & 1.429 & 4.222 & -16.510 & 15.811 \\
\hline Real interest rate & 603 & 8.450 & 14.159 & -46.633 & 84.047 \\
\hline Inflation & 797 & 5.027 & 0.300 & 4.605 & 6.062 \\
\hline Overvaluation & 766 & 0.034 & 15.259 & -84.773 & 100.296 \\
\hline Current account & 789 & -1.801 & 5.251 & -18.183 & 24.458 \\
\hline Terms of trade (\%GDP) & 806 & 60.318 & 33.251 & 11.545 & 228.875 \\
\hline
\end{tabular}


TABLE 1. (Continued)

C. Emerging/Developing Countries

\begin{tabular}{lcrrrc} 
VARIABLES & Observation & Mean & Std.Dev. & Min & Max \\
\hline Private Credit (\%GDP) & 802 & 37.345 & 30.738 & 3.907 & 210.417 \\
Financial Liberalization Index & 802 & 9.129 & 4.805 & 0 & 18 \\
Banking supervision & 806 & 0.594 & 0.732 & 0 & 3 \\
Law and order & 806 & 2.821 & 1.178 & 0 & 6 \\
Lack of corruption & 806 & 2.671 & 1.057 & 0 & 6 \\
Deposit insurance & 806 & 0.774 & 0.418 & 0 & 1 \\
Bureaucratic efficiency & 806 & 1.909 & 0.877 & 0 & 4 \\
Government stability & 806 & 7.002 & 2.124 & 1 & 11.083 \\
\hline
\end{tabular}

$$
\begin{aligned}
Y_{i, t}= & C R I S I S_{i, t}=\beta X_{i, t-1}+\delta_{1} F L_{i t-1}+\delta_{2}\left(F L_{i t-1} * F L_{i t-1}\right)+ \\
& \lambda_{2}\left(F L_{i t-1} * G O V_{i t-1}\right)+\varepsilon_{i t}
\end{aligned}
$$

Where $F L_{i t-1}$ denotes the financial liberalization variable for country $i$ at time $t-1$ and $G O V_{i t-1}$ is one of six measures used as indicators of banking sector governance and the quality of the institutional environment in country $i$. These measures are: banking supervision, deposit insurance, law and order, (lack of) corruption, bureaucratic efficiency, and government stability. Except for the variable deposit insurance, the remaining five variables sometimes exhibit a relatively high cross-correlation (up to 0.78 as shown in table 2 ) and are therefore used separately in the main logistic regressions to avoid multi-collinearity problems. ${ }^{10}$

The model in equation (4) allows for a non-linear relationship between liberalization and crisis by introducing the squared term (liberalization interacted with itself). This choice is motivated by the recent evidence in Angkinand et al. (2010), where an inverted U-shaped relationship is documented for a similar measure of liberalization and banking crisis. Their result suggests that increased liberalization (or financial reform) leads to increased probability of banking crisis up to a certain intermediate level, after which the relationship is reversed at

10. For robustness checks, we also use all six $G O V$ measures jointly in a reduced model without the interaction term $\left(F L^{*} G O V\right)$ as shown in appendix $\mathrm{D}$. While the magnitude of the coefficients differs between the joint $G O V$ and separate $G O V$ estimations, the direction and significance levels remain overall the same for each variable. 
TABLE 2. Correlation Matrix of Governance \& Institutional Measures

A. Global sample

\begin{tabular}{lcccrrr} 
& $(1)$ & $(2)$ & (3) & (4) & (5) & (6) \\
\hline Banking supervision (1) & 1.000 & & & & & \\
Law and order (2) & 0.463 & 1.000 & & & & \\
Lack of corruption (3) & 0.274 & 0.759 & 1.000 & & & \\
Deposit insurance (4) & 0.083 & 0.120 & 0.090 & 1.000 & & \\
Bureaucratic efficiency (5) & 0.462 & 0.761 & 0.781 & 0.130 & 1.000 & \\
Government stability (6) & 0.408 & 0.440 & 0.287 & -0.013 & 0.399 & 1.000
\end{tabular}

B. High-Income OECD Countries

\begin{tabular}{lrrrrrr} 
Banking supervision (1) & 1.000 & & & & & \\
Law and order (2) & 0.264 & 1.000 & & & & \\
Lack of corruption (3) & -0.067 & 0.618 & 1.000 & & & \\
Deposit insurance (4) & 0.019 & -0.144 & -0.170 & 1.000 & & \\
Bureaucratic efficiency (5) & 0.284 & 0.680 & 0.588 & -0.134 & 1.000 & \\
Government stability (6) & 0.067 & 0.149 & 0.101 & 0.019 & 0.272 & 1.000 \\
\hline C. Emerging/Developing Countries & & & & & \\
Banking supervision (1) & 1.000 & & & & & \\
Law and order (2) & 0.184 & 1.000 & & & & \\
Lack of corruption (3) & -0.074 & 0.412 & 1.000 & & & \\
Deposit insurance (4) & -0.068 & -0.102 & -0.116 & 1.000 & & \\
Bureaucratic efficiency (5) & 0.194 & 0.365 & 0.532 & -0.074 & 1.000 & \\
Government stability (6) & 0.570 & 0.428 & 0.119 & -0.130 & 0.279 & 1.000
\end{tabular}

relatively higher levels of liberalization. This is also consistent with some previous evidence showing differential long versus short-term effects of liberalization. For example, Kaminsky and Schmukler (2008) show that financial markets experience higher volatility during the first three years following liberalization but tend to become more stable later as financial institutions learn to deal with risk in the newly liberalized environment. A similar argument is developed by Daniel and Jones (2007).

Equation (4) is estimated both for the global country sample ("naïve" model) and for two sub-samples ("regional" model) by separating advanced (or high-income OECD) countries from Emerging/Developing countries.

\section{The data}

Our sample consists of a panel of 53 countries over the period 
1980-2005 which includes 48 episodes of systemic banking crises. The sample period is limited by the availability of the Financial Reform Index, which ends in 2005. ${ }^{11}$ However, this period covers well the financial liberalization periods for most of the emerging and developing countries included in our study. As mentioned above, we divide the global sample between high income-OECD countries (22) and Emerging/Developing countries (31). We include both crisis and non-crisis countries to avoid having a biased sample. This is similar to the approach used in Demirgüç-Kunt and Detragiache (1998) whereby the inclusion of non-crisis countries represents controls and allows us to fully exploit the variation in the explanatory variables to determine why crisis will or will not occur.

The most important step in the estimation of EWS models is the definition of the crisis variable. In the banking crises literature, there is no consensus on either what constitutes a systemic banking crisis or how to determine its exact starting and ending dates. Various studies adopted different definitions and criteria to determine a systemic crisis dummy. Moreover, the same crisis episode may have different durations in different studies. Also, some studies use only systemic crises, while others use both systemic and non-systemic banking crises. Davis and Karim (2008) provide a helpful discussion of the various definitions used in some of the major studies in this literature. ${ }^{12}$

In our study, we rely on the most recently updated database of systemic banking crises provided by Laeven and Valencia (2008). The advantage of this comprehensive database is that it builds on previous studies but excludes banking distress events that are not systemic in nature (affecting isolated banks). However, the authors only provide starting dates for the identified crisis episodes. We use this information in combination with Caprio and Klingebiel (2003) database to construct

11. The database of Abiad et al. (2008) actually contains 91 countries for which they compute the Financial Reform Index, but many of the explanatory variables used in our paper are not available for all countries. Thus our sample of countries is also limited by data availability.

12. For instance Caprio and Klingebiel $(1996,2003)$ focus on the solvency side of crisis and define systemic crisis as an event when "all or most of banking capital is exhausted". Demirguc-Kunt and Detragiache (1998) used a specific set of four criteria where the occurrence of at least one of them reflects the onset of a systemic banking crisis. Kaminsky and Reinhart (1999) use similar criteria and define a crisis as systemic if bank runs result in closure or nationalization of at least one bank, or if there are no runs, large-scale government intervention, merging or nationalization of one bank marks the beginning of the same for other banks. Any other episodes of banking distress are considered as non-systemic crises. 
our systemic banking crisis dummy (see appendix A for a list of countries and the corresponding systemic crisis periods).

For the liberalization variable, there is also no consensus in the literature and many studies use different definitions for financial liberalization as mentioned in the previous section. For instance, according to Kaminsky and Schmukler (2008), financial liberalization has three dimensions: real domestic liberalization, financial markets liberalization and capital account liberalization. Similarly, in Neumann et al. (2009), the degree of financial liberalization is measured by an index composed of the domestic financial sector, the financial markets and the capital account, and which varies between 1 and 3 , for each component: a value of 1 indicates no liberalization, 2 indicates partial liberalization, and 3 indicates full liberalization. Other indicators of financial liberalization in the literature include dummy variables based on dates such as those of equity market liberalization, and are used to classify a country as either liberalized (value of 1) or repressed (value of 0 ).

In this study, we use the Financial Reform Index from the recent International Monetary Fund Financial Reforms Database proposed by Abiad et al. (2008). This measure is more comprehensive than all other available liberalization measures. It considers many dimensions of financial sector reform, on an annual basis, reflecting various stages of liberalization and various intensity levels. Further, the coding along each dimension is a graded score (rather than binary) and allows for reversals from liberalized to repressed regimes when necessary. The seven dimensions included in computing the aggregate Financial Reform Index (FRI) are: 1) credit controls and reserve requirements, 2) interest rate liberalization, 3) banking sector entry barriers, 4) capital account restrictions, 5) privatization, 6) securities markets liberalization, and 7) capital regulation and prudential supervision of the banking sector. The aggregate Financial Reform Index varies between 0 and 21, from fully repressed to fully liberalized. However, as acknowledged by Abiad et al. (2008), the $7^{\text {th }}$ dimension is different from the other six dimensions that can be viewed as liberalization enhancing reforms. Therefore, we follow Shehzad et De Haan (2009) and Angkinand et al. (2010) and construct a modified version of the FRI based only on the sum of scores for the six first dimensions, resulting in an aggregate liberalization score (used as $F L$ in model (4)) that varies between 0 (fully repressed) and 18 (fully liberalized).

For the variables $G O V$, we use the following six indicators: banking supervision, law and order, (lack of) corruption, deposit insurance, 
bureaucratic quality and government stability. These variables have been largely debated in the financial literature and shown to be important indicators of the quality of governance and institutional environment in various countries. For banking supervision, we use the $7^{\text {th }}$ dimension in the Abiad et al. (2008) database mentioned above. The score varies from ( 0 ) for unregulated and unsupervised, through (1) for weakly regulated and supervised, (2) for largely regulated and supervised, and (3) for strongly regulated and supervised banking sectors. Based on previous literature, we expect to see a negative coefficient for the interaction term between this variable and FL. In other words, stronger banking regulation and supervision should weaken a potential positive relationship between liberation and systemic banking crisis. For deposit insurance, we use the Demirgúç-Kunt et al. (2005) database which assigns a value of (1) if there is explicit deposit insurance and (0) for implicit deposit insurance. Previous literature shows that explicit deposit insurance adds to the moral hazard problem and reduces market discipline. We therefore expect to see a positive impact of this variable on the relationship between FL and crisis.

All other institutional variables are from the International Country Risk Guide (ICRG) database. The variable "Law" provides a measure of law and order tradition in a country. A maximum of 6 is assigned for countries with strong law and order tradition and a low of 0 is assigned for weak law and order tradition. The indicator of corruption ranges from 0 (high level of corruption) to 6 for low levels of corruption. The variable "Bureaucracy" is a measure of bureaucratic efficiency. A maximum of 4 is assigned to countries where bureaucracy has the strength and expertise to govern without drastic changes in policy or interruptions in government services. Finally, the variable "Stability" provides an indicator of the government ability to carry out its declared $\operatorname{program}(\mathrm{s})$ and its ability to stay in office, with a maximum value of 12 indicating very low risk and zero indicating very high risk. Based on previous literature on the beneficial effects of better governance and improved quality of institutions on the financial sector, we expect to see negative coefficients for the above-mentioned ICRG measures in the logistic regressions to predict crisis probability. However, this relationship may vary depending on where the country is situated on the liberalization process, which is why we are interested in studying the interaction effects between $F L$ and $G O V$ as specified in equation (4).

The basic explanatory variables used in the first stage regressions include standard macroeconomic and financial variables that have been 
identified in previous literature as significant to predict the probability of systemic banking crisis. These variables are: real GDP per capita growth rate, inflation rate, the ratio of current account to GDP, the change in the terms of trade, real interest rates, the ratio of private credit provided by the banking sector as percentage of GDP and exchange rate overvaluation. ${ }^{13} \mathrm{~A}$ definition of all the control variables and their sources is provided in appendix B. Table 1 provides summary statistics for all the data used in this study. As shown in Panels B and C, there are important differences between the High Income-OECD group and the Emerging/Developing countries group, particularly at the levels of banking supervision (averaging 1.52 vs. 0.59 ), but also in terms of bureaucratic quality (3.67 vs 1.91 ), corruption (4.86 vs. 2.67), law and order (5.34 vs. 2.82 ), and government stability ( 8.25 vs 7.00$)$. We also note, as expected, a higher level of financial liberalization for the OECD group compared to the other countries (average of $14.56 \mathrm{vs}$. 9.13). This justifies the use of the "regional" estimation approach since the countries in each group, are on average, at different levels of the financial reform process as well as in terms of governance and institutional quality.

\section{Empirical results}

\section{A. Main results}

We first estimate panel logit regressions that include only basic controls including macroeconomic and financial indicators selected from previous literature without the liberalization and governance measures. The results from this first stage estimation are reported in appendix $\mathrm{C}$. When we use the global sample of all 53 countries, only four control variables are significant in predicting the probability of a systemic banking crisis. However, different sets of variables are significantly related to the likelihood of crisis for the two country groups. The signs of most coefficients are overall consistent with previous literature. The negative and mostly significant coefficient for real per capita GDP growth both at the global and "regional" levels confirms that the likelihood of banking crisis increases with lower GDP growth rates. The

13. Other control variables are also used for robustness checks as described in section IV.B below. 
coefficient on inflation is also highly significant and negative in all samples while the coefficient on real interest rate is consistently positive and significant across all estimations. The coefficient for the terms of trade is highly significant only for the Emerging/Developing countries group, while the coefficient for private credit to GDP is highly significant only when we restrict the sample to high income-OECD countries only. Its positive sign suggests that a deeper banking sector relative to the size of the economy is associated with higher likelihood of banking crisis. The coefficient on exchange rate overvaluation is only significant for the Emerging/Developing countries group. Finally, the variable current account is not significant at the global sample level, but turns out significant and with opposite signs when we use "regional" groupings pointing to opposite effects that tend to cancel out at the global sample level. All this confirms the usefulness of the "regional" approach in order to detect the most significant crisis indicators for each class of economies and be able to use different determinants of crisis when studying the effects of liberalization and its interaction with banking governance and institutional quality. The direction of some variables changes depending on the sample and model used, but based on previous literature, the sign is not always consistent across studies and seems to vary depending on the sample and period.

Next, we turn to the main focus of the paper and rerun the logit model by introducing the financial liberalization variable $(F L)$ and its interaction with various indicators of banking governance and institutional variables $(G O V)$ as shown in equation (4). At this stage, we only keep the significant macroeconomic controls identified in the first stage estimation to reduce idiosyncratic noise and maximize the number of observations in the model estimation for each sample. ${ }^{14}$ We report the results of these estimations in table 3 for the global sample used as a benchmark, and in tables $4 \& 5$ for the high income-OECD and Emerging/Developing countries respectively. The liberalization $(F L)$ variable is measured by the modified version of the Financial Reform Index (Abiad et al. 2008) as described in the data section. The coefficients on the control variables all have similar signs and significance levels as in the fist step estimations reported in appendix $\mathrm{C}$ before introducing the variables $F L$ and $G O V$. Therefore we focus our analysis on the liberalization and governance effects.

14. Note that a larger set of macroeconomic and financial control variables were tested in this step as explained in the robustness checks section below. 


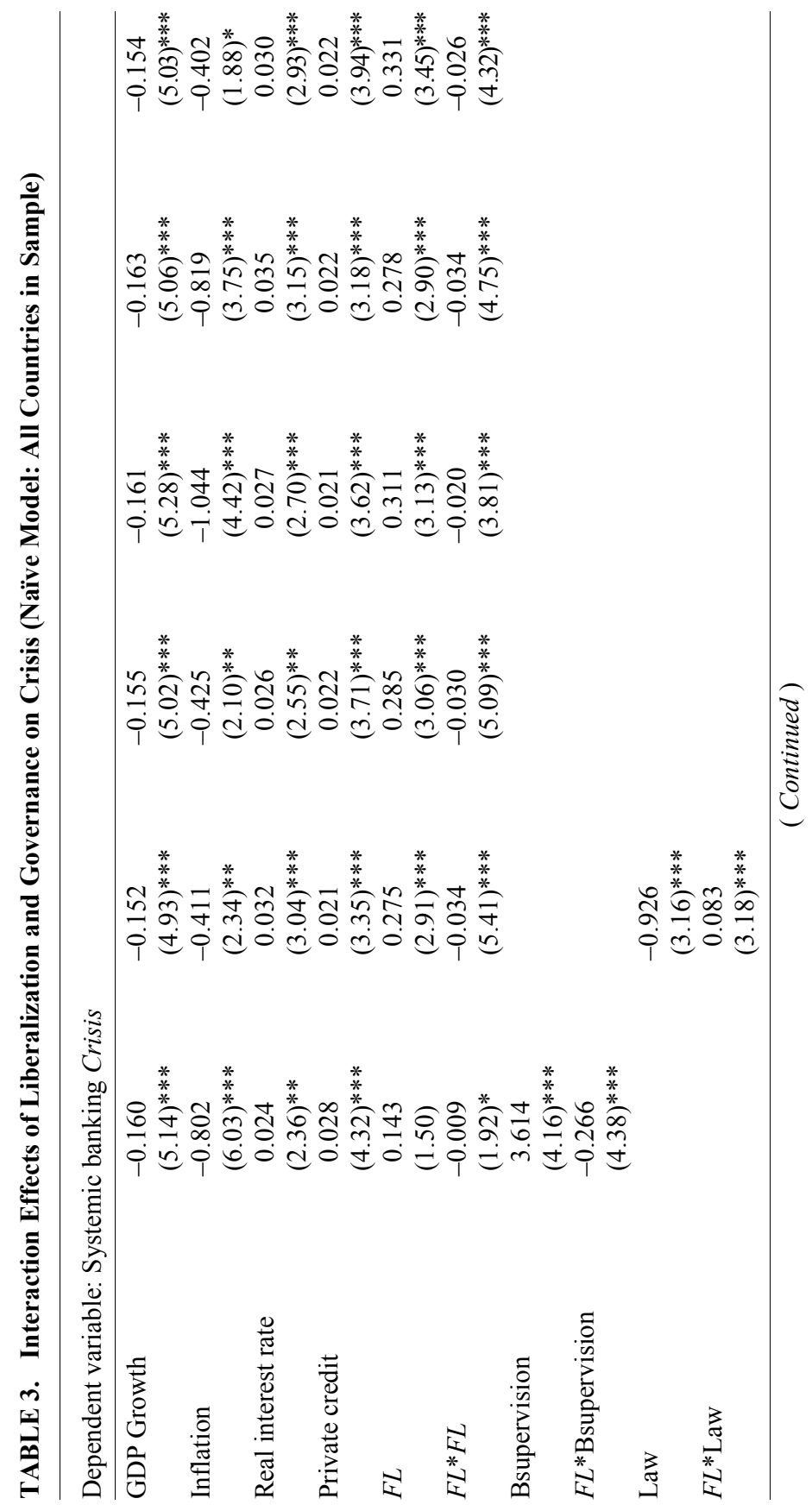




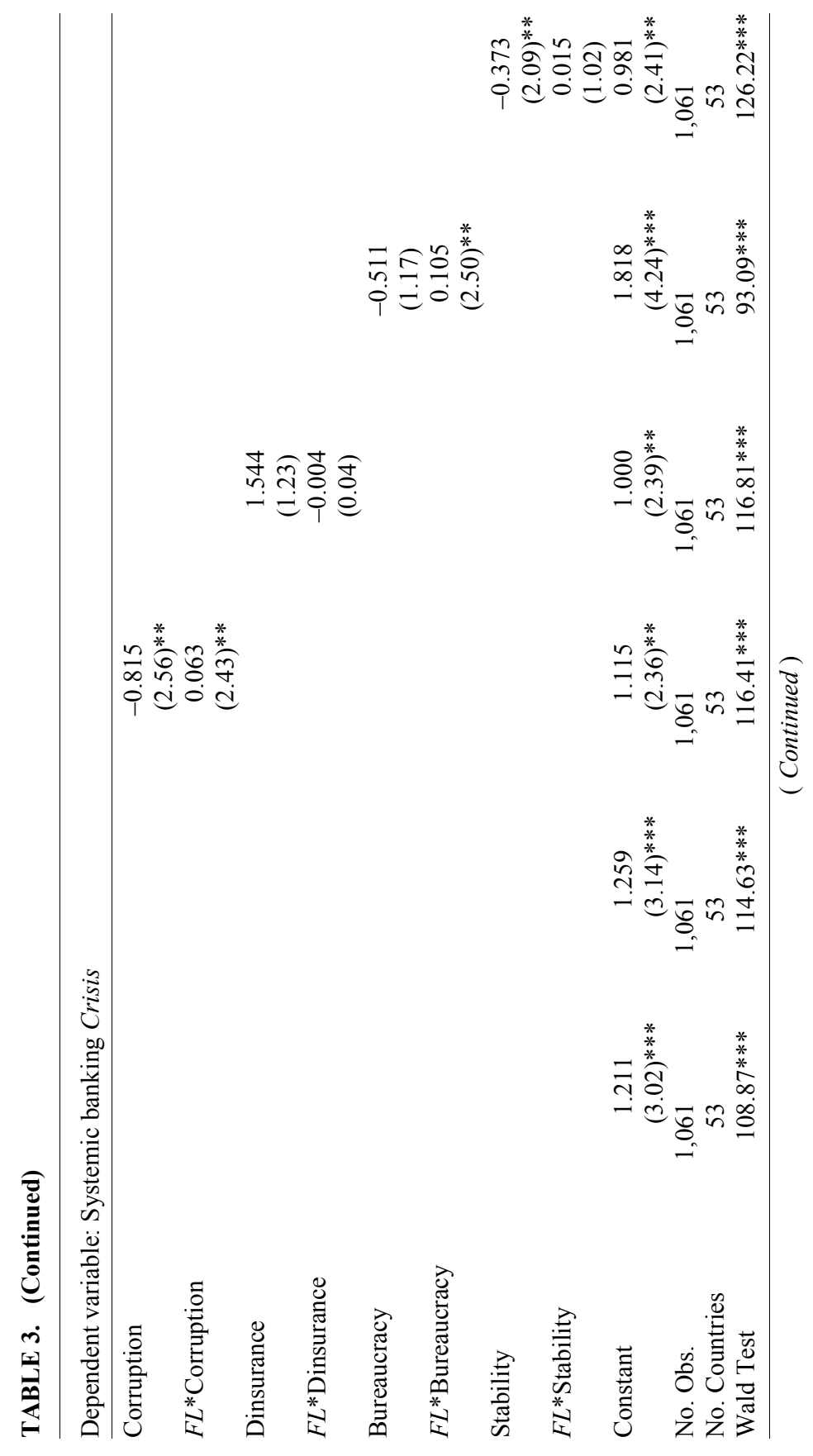




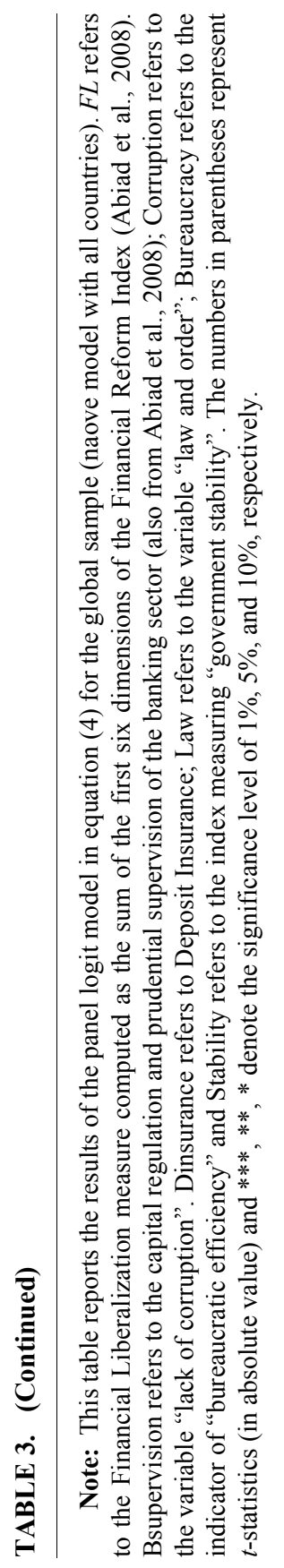


Similar to Angkinand et al. (2010), we find a positive coefficient for the $F L$ variable while its squared term has a negative coefficient for all the specifications shown in tables 3-5. This confirms the inverted U-shaped relationship between liberalization and systemic banking crisis. Thus, increased financial reform, moving from repressed to relatively higher levels of liberalization of the financial system, initially increases the likelihood of systemic banking crisis up to a certain threshold, after which additional liberalization measures result in decreasing probability of crisis and reaches a minimum as countries move closer to being fully liberalized. Interestingly, we note that this inverted U-shaped relationship holds in the presence of the $G O V$ variables and their interaction with $F L$, regardless of whether we use a "naïve" model based on all countries or a "regional" estimation approach. However, the statistical significance of the coefficients on $F L$ is largely reduced for the high income-OECD sample, while remaining highly significant for the sample of Emerging/Developing countries.

Next, we focus on the impact of the $G O V$ variables, while still accounting for financial liberalization effects. Our initial expectations were to see negative coefficients suggesting that better governance is associated with lower likelihood of crisis. This expectation is confirmed for most $G O V$ measures when used without considering their interaction with liberalization as shown in appendix D. However, some interesting differences are revealed in the full model accounting for interaction effects as reported in tables 3-5. For instance, the coefficient on banking supervision as a separate control variable is positive and highly significant for all samples, while its interaction with $F L$ yields a negative and highly significant coefficient. The positive coefficient on the level of this variable indicates an increase in the likelihood of crisis. However this increase is mitigated by the interaction term with liberalization as show by the negative coefficient. This result is consistent with the study by Angkinand et al. (2010), which uses similar measures for liberalization and banking regulation and supervision. Note that when we exclude the interaction term from the model (as shown in appendix D), the overall impact of banking supervision is negative, suggesting that stronger stricter banking regulation and supervision reduces the probability of crisis. The magnitude of the coefficient suggests that the impact of the $F L^{*} G O V$ relationship on crisis is much stronger for high income-OECD countries than for Emerging/Developing countries. To help with the interpretation of the sign and direction of the impact of this governance measure on crisis 


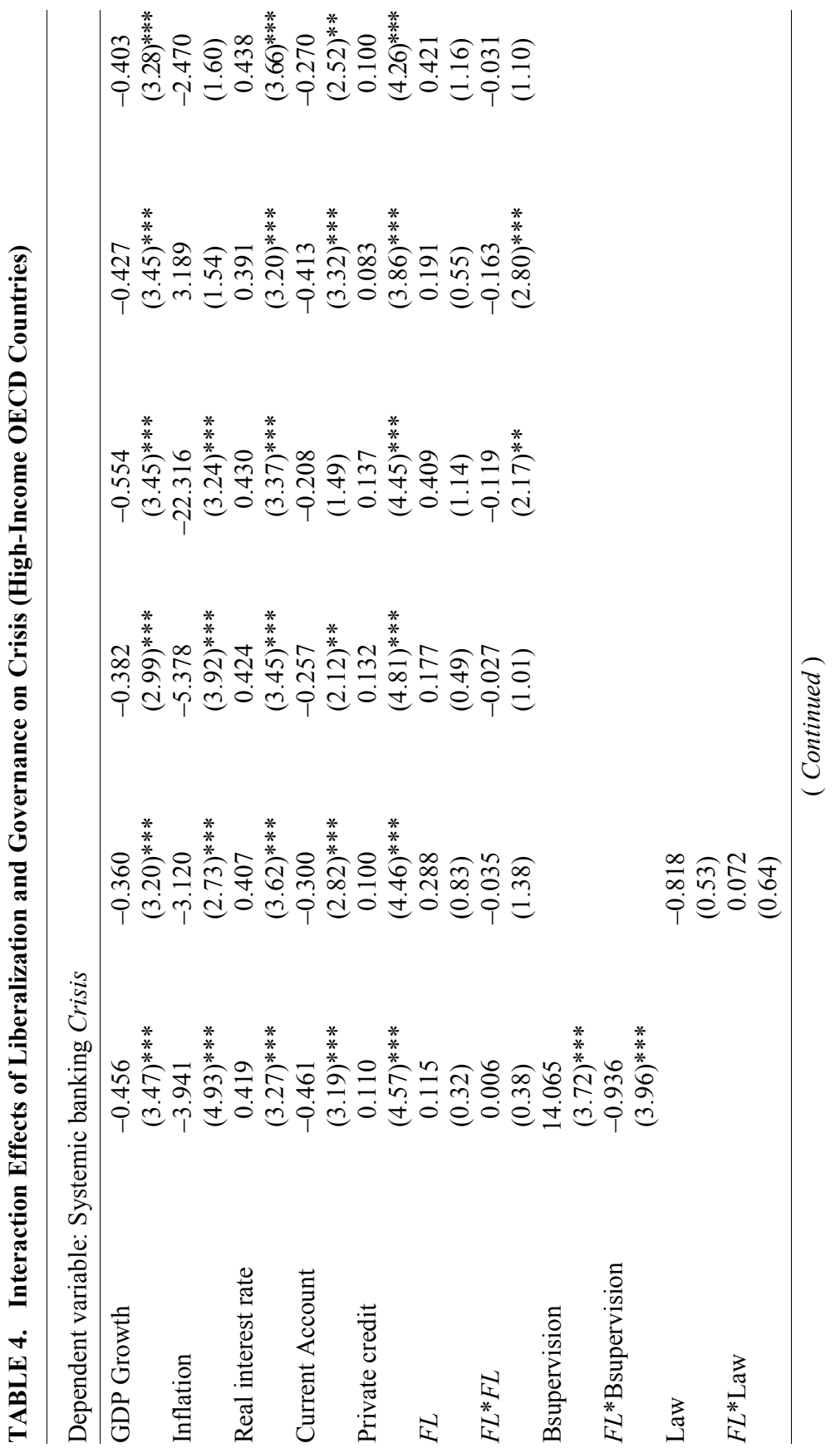




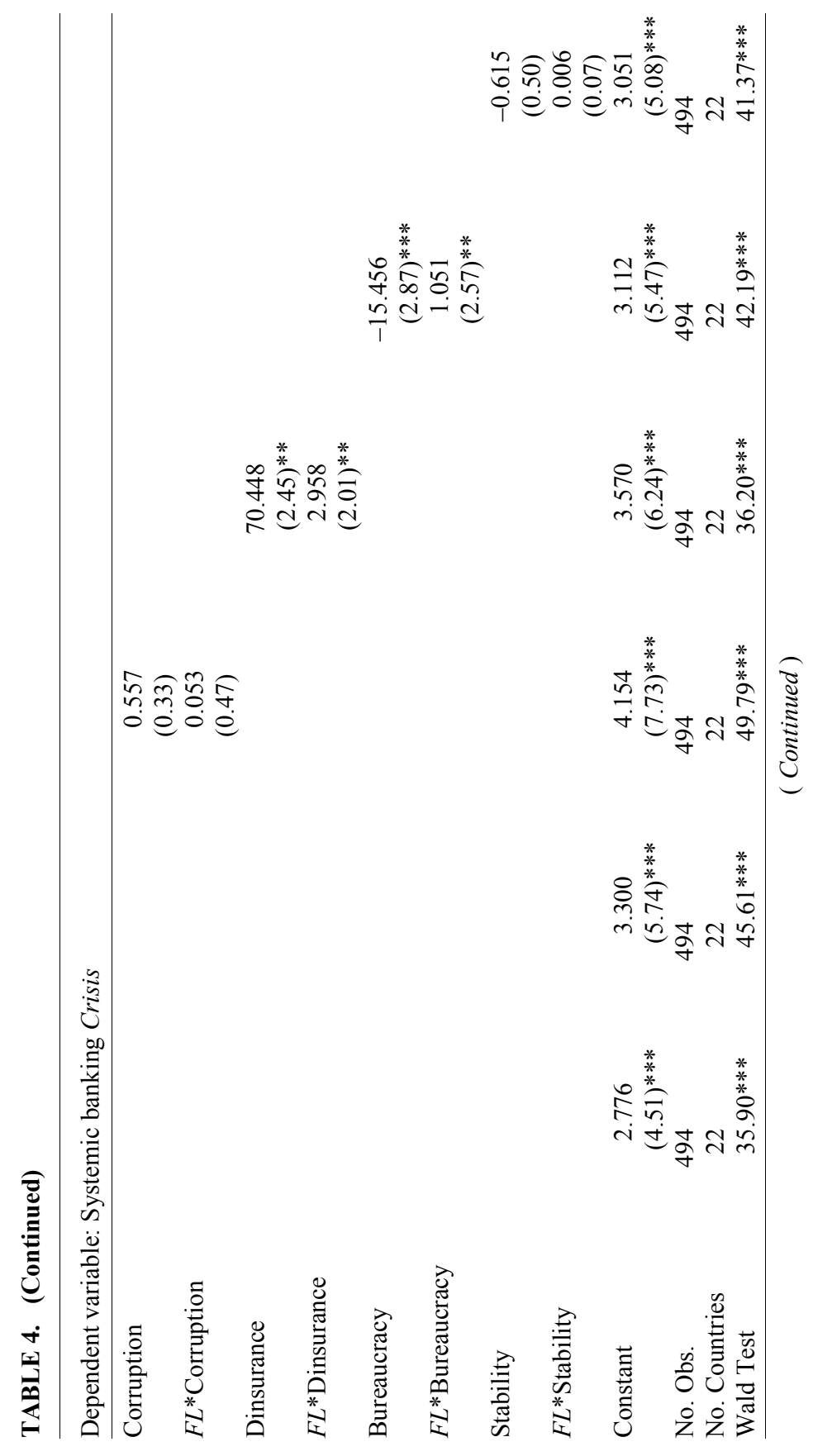




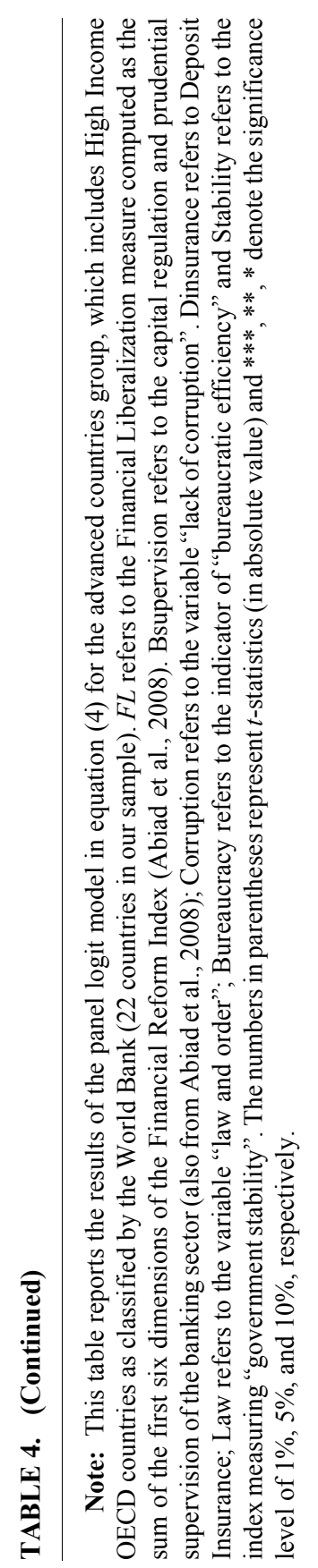




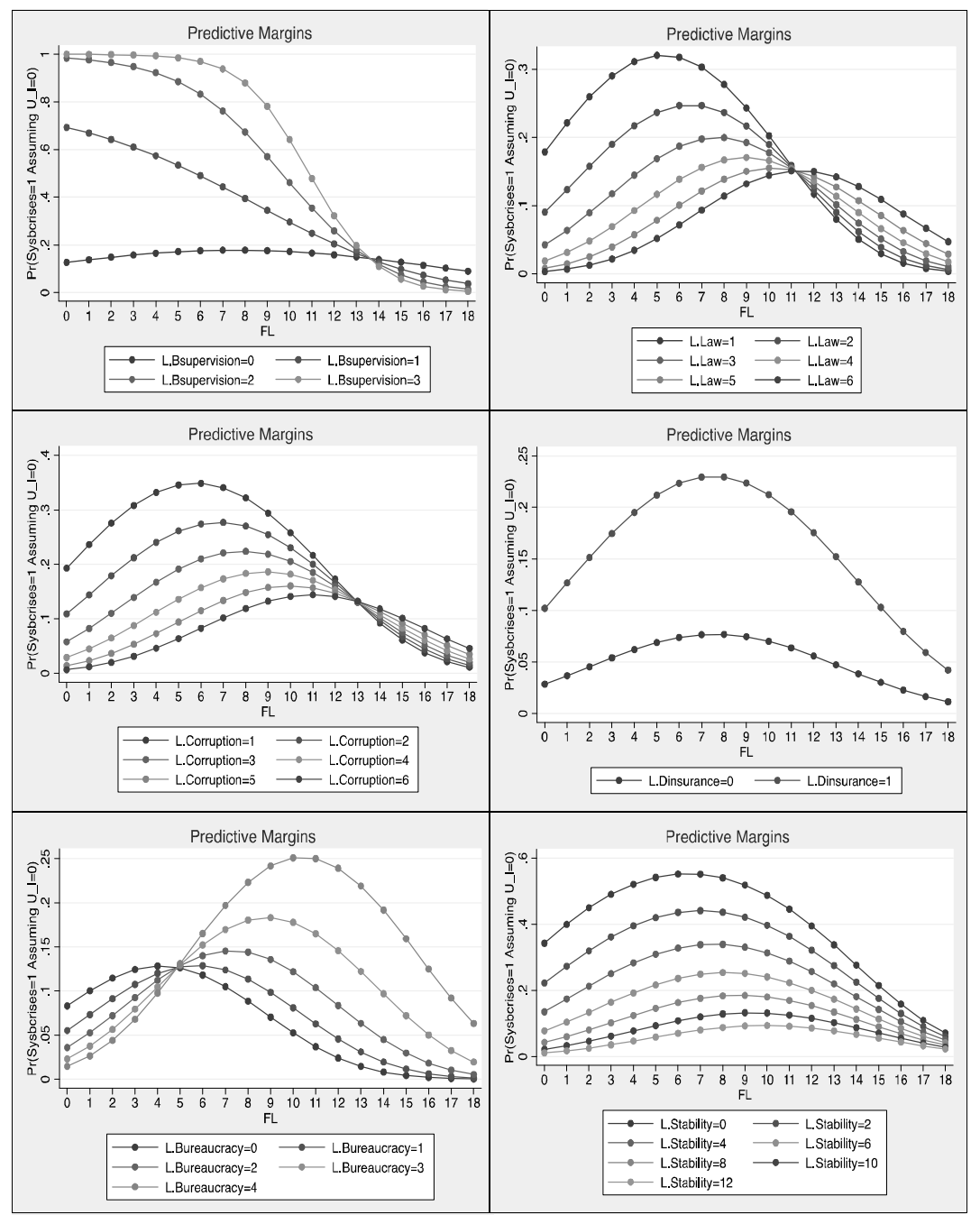

FIGURE 1.- Predicted Probability of Crisis for the Global Sample (With level and interaction effects of GOV)

Note: This figure shows the predicted probability of systemic banking crisis estimated from the coefficients in table 3 (all countries, including interaction and level effects of $G O \mathrm{~V}$ ) for different levels of financial liberalization at different levels of governance and institutional quality measures. Definitions of the $G O V$ variable names are as per table 3 . 


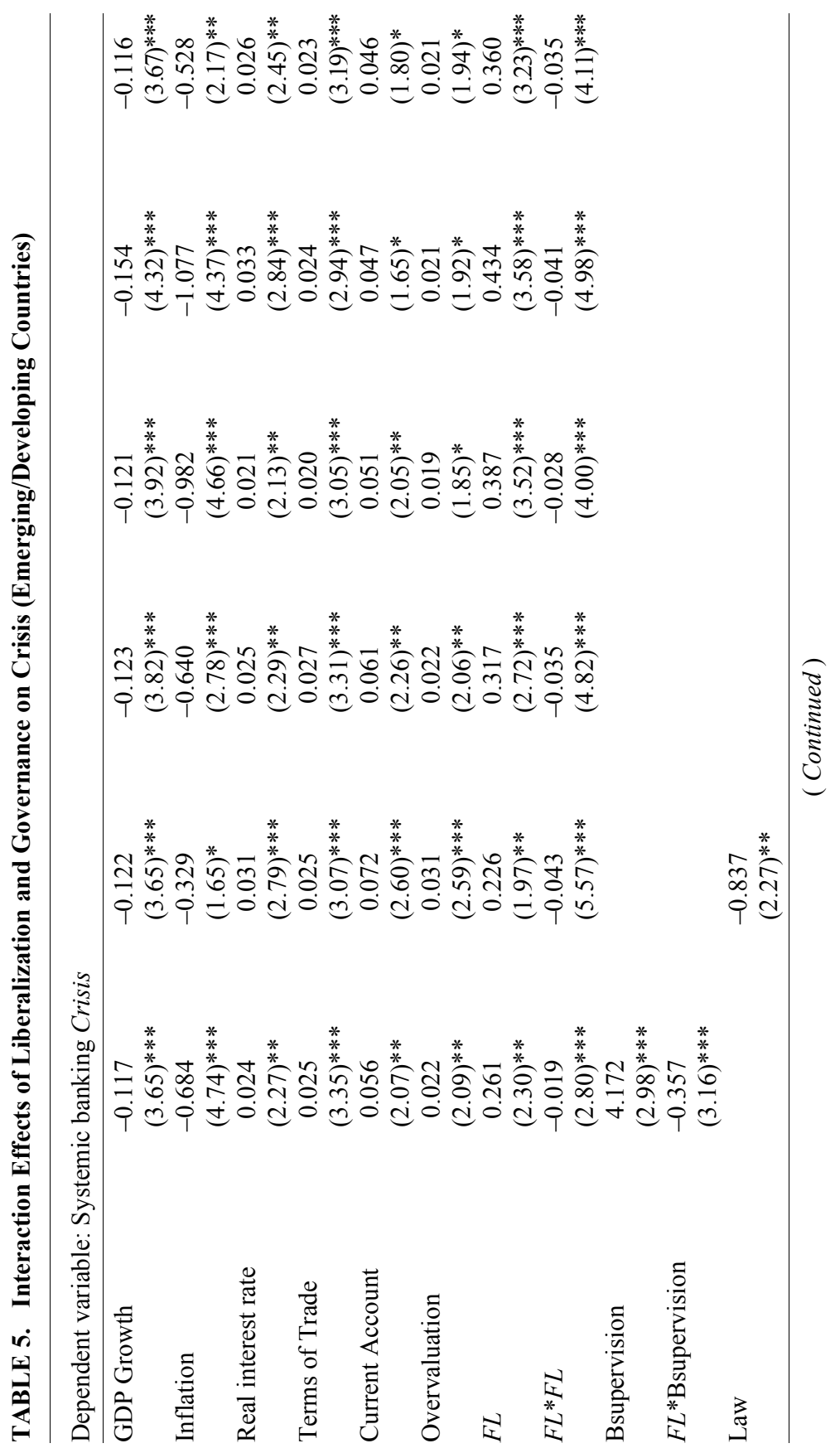




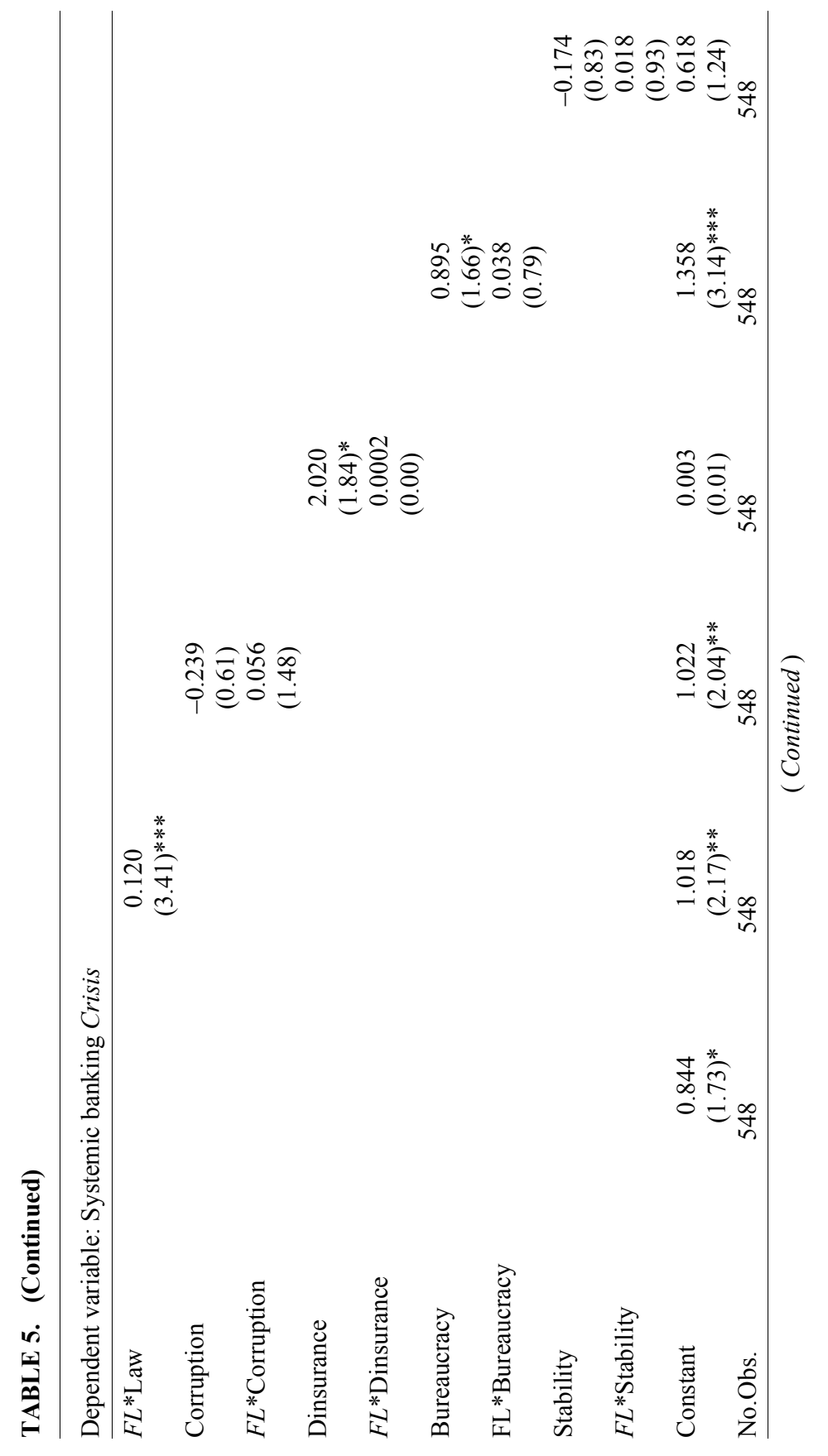




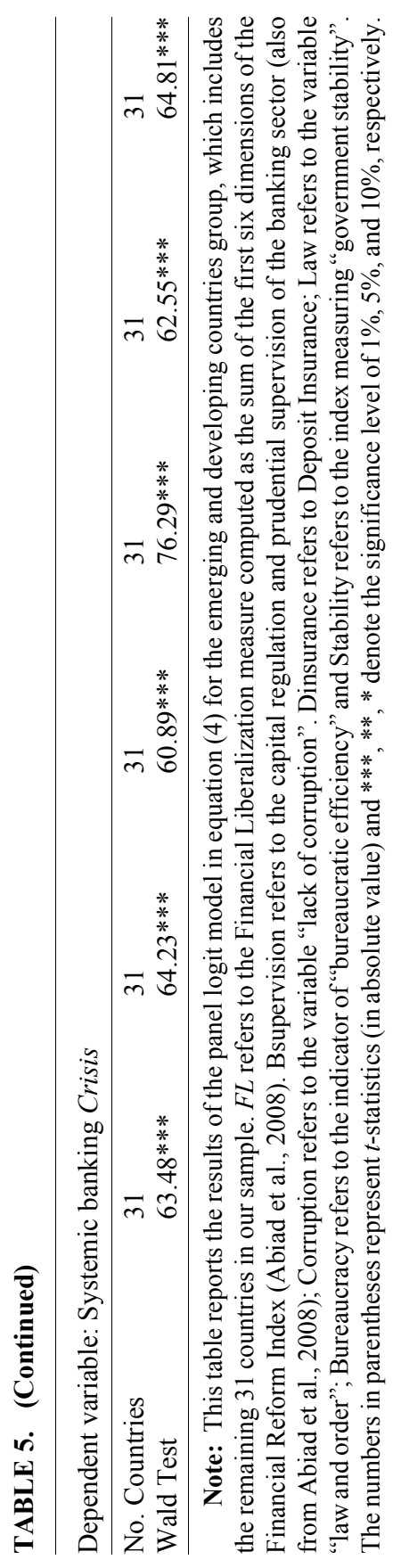


(both in level and when interacted with $F L$ ), we refer to the top left graphs in figures 2 and 3 for each country group as discussed below.

We also note interesting differences for the other $G O V$ measures across the various samples. At the global sample level, all other $G O V$ measures (except deposit insurance) have negative and mostly significant coefficients on the separate effects, but positive coefficients on the interaction effects with varying degrees of significance. However, when separating high-income OECD countries from the Emerging/Developing countries, we find that the impact of the variable "law and order" is much stronger (both in statistical significance, and in magnitude of the interaction term) for Emerging/Developing countries. On the other hand, the variable (lack of) corruption, which is highly significant in the global sample, looses its significance when comparing economies with more or less similar characteristics within each country group. The coefficient on government stability remains negative but is not significant in the "regional" model. This can be explained by the fact that other significant control variables have been included for each group of countries, compared to the basic controls used for the global sample. The coefficient on bureaucratic efficiency is much stronger both in magnitude and significance for the OECD sample, and so is the impact of deposit insurance, which yields very large and highly significant coefficients for high income-OECD countries.

To provide an easier interpretation of the results described above, we plot the predicted probabilities of crisis showing marginal effects of each $G O V$ measure at different levels of financial liberalization. We focus our analysis on the differences between the two country groups as illustrated by figures 2 and 3 for the high income-OECD and Emerging/Developing countries respectively. First, for banking supervision, we see that at very weak levels of supervision (value of $(0)$ ), increasing the liberalization level is associated with relatively higher probability of crisis for OECD countries, while for the sample of Emerging/Developing countries we see an initial increase followed by a decrease in the likelihood of crisis at higher levels of liberalization. For countries with stronger levels of banking supervision, we note a sharp drop in the probability of crisis with a steeper decline for stronger banking supervision values (going from 3 to 1 ). For all samples, we see a turning point (achieved earlier for Emerging/Developing countries as shown in the graphs) indicating the existence of a threshold in the degree of liberalization after which we always obtain lower probability of crisis with stricter banking supervision, although the difference in 


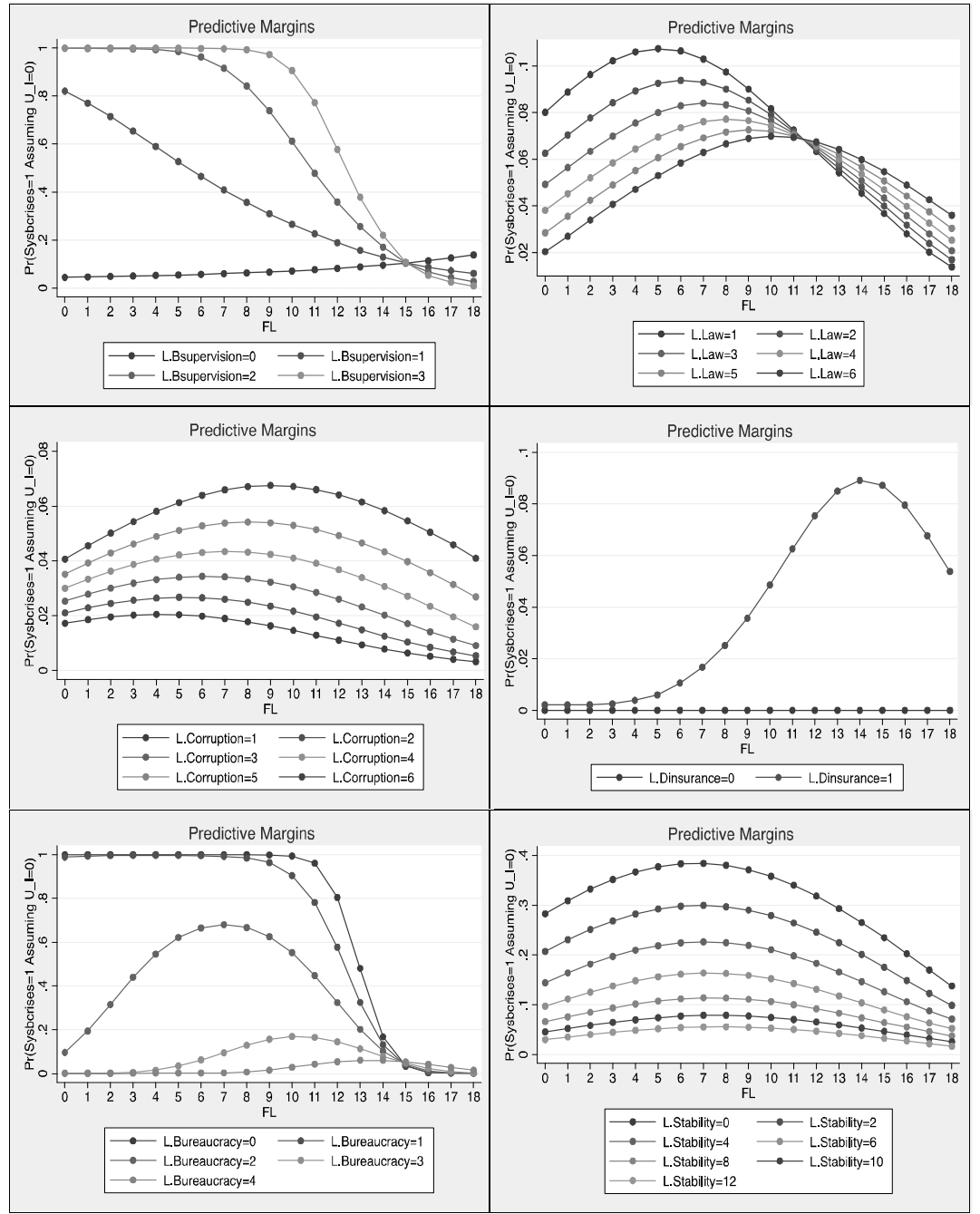

FIGURE 2.- Predicted Probability of Crisis for High-Income OECD Countries (With level and interaction effects of GOV)

Note: This figure shows the predicted probability of systemic banking crisis estimated in table 4 for different levels of financial liberalization at different levels of governance and institutional quality measures. Definitions of the $G O V$ variable names are as per table 4. 

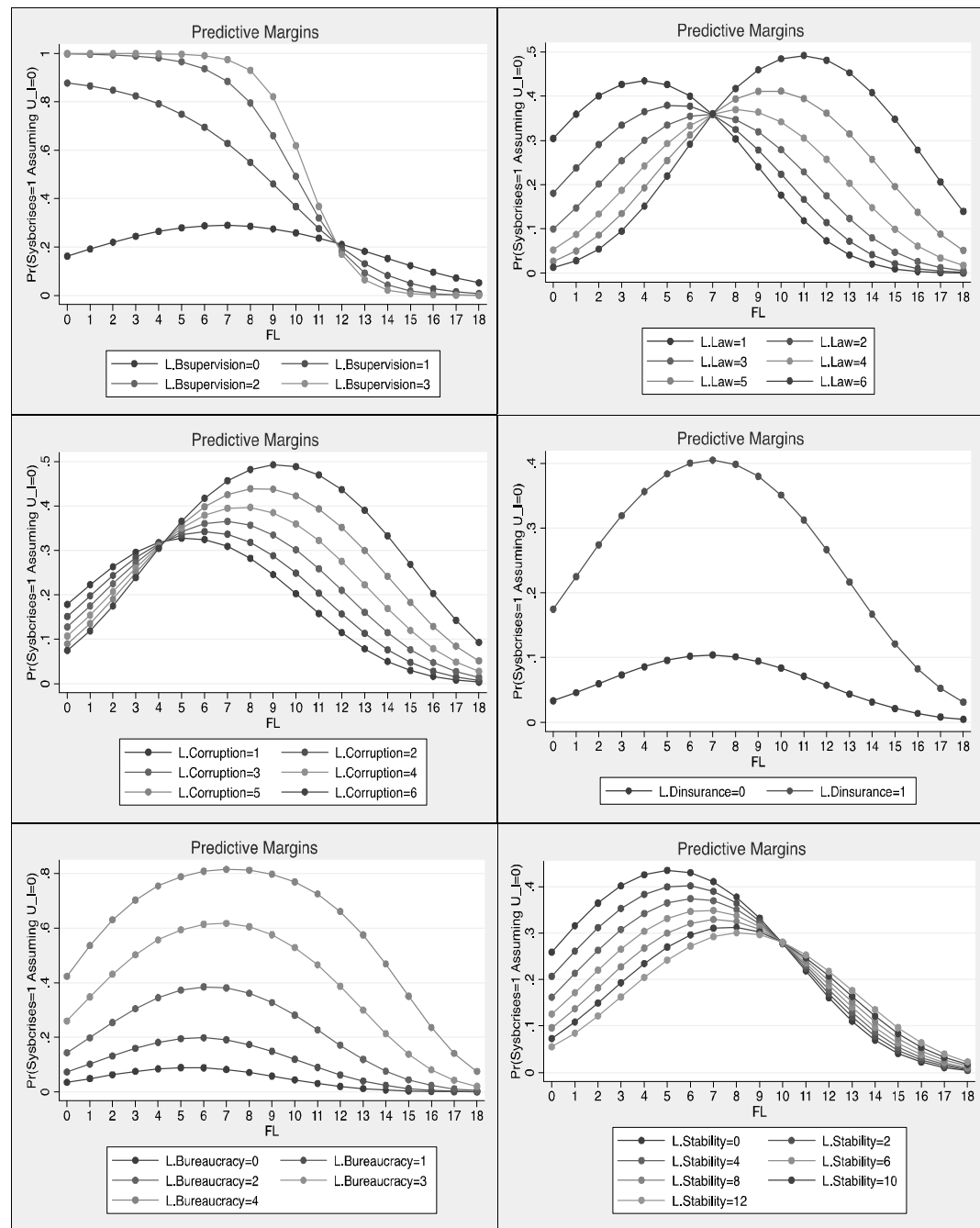

FIGURE 3.- Predicted Probability of Crisis for Emerging/ Developing Contries (With level and interaction effects of GOV)

Note: This figure shows the predicted probability of systemic banking crisis estimated in table 5 for different levels of financial liberalization at different levels of governance and institutional quality measures. Definitions of the $G O V$ variable names are as per table 5. 
marginal effect does not seem very large across the various levels of the GOV measure.

For the variable law and order, we see higher probability of crisis associated with poor legal systems (value of (1) as shown by the blue line for both country groups) at relatively lower levels of financial liberalization. At all levels of the law and order measure, the probability of crisis initially increases with increased liberalization reforms and then starts to decrease at higher levels of liberalization. This result holds regardless of the sample countries, however, there are important differences across the two groups of countries in such turning point when liberalization starts to have beneficial effects. For high income-OECD countries, we note that the steepest decline in the probability of crisis as we move to higher degrees of liberalization is achieved in the presence of poor legal environment (value of (1)). Beyond a certain level of liberalization, the marginal effect of the Law measure becomes rather small, though still decreasing as a function of liberalization. ${ }^{15}$ For Emerging/Developing countries (in figure 3), the decline in the likelihood of crisis starts to occur at lower values of liberalization in poor legal environments (at about $F L=4$ for $L a w=1$, the blue line) while such beneficial effect of liberalization starts to occur at much higher levels of $F L$ for stronger legal environments (at about $F L=11$ for $L a w=6$, the red line). This suggests that the increased competition and market openness that accompany financial liberalization may help mitigate the negative impact of poor legal systems on financial stability and the likelihood of crisis.

We obtain a similar result for the impact of (lack of) corruption and government stability for the Emerging/Developing markets group, with interaction effects that vary depending on the level of liberalization. This is different from the results for the high income-OECD countries (figure 3), where we always obtain lower probability of crisis with better government stability regardless of the level of liberalization, although we see a steeper decline in crisis probability for the lowest value of government stability.

The impact of the (lack of) corruption seems counter intuitive for the OECD sample, but it is worth noting the very small marginal effects as show by the $Y$ axis in figure 3 for the corruption measure (ranging from

15. Note that although the FL measure is on average higher for OECD countries (with a mean value of 14.5), there is still a large variation across countries in this group based on the financial reform indicator with a standard deviation of 3.6 and individual levels ranging from 2 to 18 . 
0.02 to about 0.07 ), which, combined with the insignificant coefficient does not suggest that (lack of) corruption plays an important role for the advanced countries group. However, when both advanced and developing countries are used in the same model as shown in table 3, the coefficient on corruption is highly significant both in level and in interaction with liberalization. The lack of significance of this variable within each country group can be interpreted as due to the similarity in levels of corruption measures within each group, while more cross-country variation in the sample points to the existence of a net negative relationship between (lack of) corruption and likelihood of crisis.

Looking at the impact of deposit insurance, first, we note a higher predicted probability of crisis associated with the presence of explicit deposit insurance (value of (1)) compared to implicit deposit insurance (value of $(0)$ ), both at the global sample and for the two country groups. The positive coefficients on deposit insurance is in line with our expectations based on previous literature showing that explicit deposit insurance adds to the moral hazard problem and reduces market discipline. However, even in the presence of explicit deposit insurance, we note a decline in the crisis probability with higher values of liberalization, which starts much earlier for the Emerging/Developing markets group (at about $F L=7$ ) compared to the high income-OECD countries (at about $F L=14$ ). ${ }^{16}$

Finally, it is worth noting that the impact of bureaucratic efficiency on the relationship between liberalization and crisis also differs substantially across the two country groups. First, for high income-OECD countries, the predicted crisis probability is much lower with better bureaucratic quality measures (lower line associated with a value of (4) in figure 3 for all levels of $F L$ up to about 15). However, we also see a decline in the likelihood of crisis after a certain level of liberalization is achieved regardless of the bureaucratic efficiency level. Interestingly, the steepest and most important decline is associated with poor bureaucratic quality levels (at a value of (0)). At very high levels of liberalization (at about $F L=15$ ), the level of bureaucracy has almost no impact on the likelihood of crisis. In contrast, for Emerging/Developing countries, and beyond the more pronounced inverted U-shaped relationship between crisis probability and

16. Note that almost all countries in the high income-OECD sample have values of 1 for the deposit insurance variable (the group average is 0.95 ). This explains the difference in the predictive margins curves shown in figure 3 for deposit insurance. 
liberalization compared to the previous sample, we find that the predicted crisis probability is always higher at higher levels of bureaucratic efficiency. On the other hand, the steepest or rapid decline in the crisis probability observed at higher levels of financial liberalization is achieved in the presence of better bureaucratic quality (at a value of (4)).

To conclude, and based on the Financial Reform Index as a more comprehensive measure of liberalization, our results suggest that in general, financial liberalization tends to increase the likelihood of systemic banking crisis at initial stages of the financial reform process, but there seems to be a threshold level after which higher degrees of financial liberalization lead to lower probability of crisis. This result is consistent with Angkniand et al. (2010) and other studies mentioned in the review section documenting increased probability of crisis following the first years of liberalization while the effect is different at longer time horizons. Further, more interesting and novel findings are revealed when we study the relationship between crisis and liberalization conditional on the countries institutional environment and the quality of the banking sector governance. While there is evidence that, overall at the global sample, improved measures on most governance dimensions, are associated with lower probability of $\mathrm{crisis}^{17}$, this beneficial governance effect operates differently at different levels of liberalization and for different types of economies. Indeed, the introduction of interaction effects in the logistic regression model and the use of the "regional" estimation approach help disentangle such differences and nuances as shown by the results in tables 4 and 5 and in figures 2 and 3 . Moreover, these results suggest that the type of institutional variables that may be most significant in mitigating the initial negative liberalization effect on crisis also seems to vary across countries and their level of development or income. Further analysis based on more specific characteristics at the individual country level would help identify more precisely the most significant institutional and governance variable(s) that policy makers should target in priority to help reduce the likelihood of crisis or limit its severity when implementing new liberalization enhancing financial reforms.

17. This result is stronger when we account for the effects of governance as separate control variables only (without interaction terms), regardless of whether they are used jointly or individually, as shown by the results reported in appendix D and the corresponding figure 4. 


\section{B. Robustness checks}

We perform a number of robustness checks, first with respect to the macroeconomic control variables included in the initial regressions, and second with respect to how the $G O V$ variables are included in the model.

Based on previous literature on the determinants of systemic banking crises, we also include in the model additional controls such as the ratio of M2 to Reserves and short-term debt to external debt. None of these variables is significant in any of the estimations, except that their inclusion reduces the number of observations substantially (for example, from 1040 in the model with basic controls shown in column (1) of appendix C, to 779 when we introduce M2/Reserves and 557 when we add the debt indicator). A similar reduction in the number of observations is obtained for the two subsamples while none of these additional control variables is significant to explain crisis probability. Therefore, for the benefit of maximizing the number of observations and limit the number of parameters in the model estimation, we ignore these variables in the main specifications that include both $F L$ and $G O V$ indicators as discussed in section IV.A above.

With respect to the $G O V$ variables, we also explore their use in the panel logit model with a two-year lag instead of one-year lag as in the main results reported above. The rationale for this is that changes in quality of the institutional environment may take time before they start having an impact on the stability of the financial sector. Interestingly, only the banking supervision variable seems to become more strongly related (with significance levels higher than 1\%) to the likelihood of systemic banking crisis when introduced with a two-year lag. This result holds for both the global sample and the Emerging/Developing countries sample, while there is no change in the significance of this measure for high income-OECD countries whether we use a one-year or a two-year lag. For the other $G O V$ measures, the results remain largely unaffected with higher lags.

Next, we re-run all the models shown in tables 3 to 5 by dropping the $G O V$ measures as separate explanatory variables and keep only their interactions with financial liberalization. ${ }^{18} \mathrm{We}$ focus our analysis on the "regional" analysis and report the results in tables 6 and 7. Table 6

18. This specification with interaction terms only was the main specification used in a previous version of the paper, and we thank an anonymous referee for emphasizing the importance of including separate effects of the $G O V$ variables as we now report in the paper. 
shows the results of this reduced model specification for the high income-OECD sample. The interaction terms are negative for all GOV measures except for (lack of) corruption and deposit insurance. This result is consistent with that obtained in table 4 when we include separate effects for the GOV measures. Furthermore, the interactions between $F L$ and corruption and between $F L$ and stability are both significant once the level of the $G O V$ variable is excluded while that between $F L$ and Bureaucracy is no longer significant once the level of the $G O V$ variable is excluded. The most significant interaction terms in the absence of level effects of $G O V$ are obtained for banking supervision and government stability. In table 7, we report the results of the reduced model for the Emerging/Developing countries sample. The positive coefficients on the interaction terms are consistent with the results shown in table 5 including level effects for $G O V$, but show higher statistical significance in the reduced model. Specifically, the interactions between $F L$ and corruption and between $F L$ and bureaucracy are both highly significant once the level of the $G O V$ variable is excluded.

Finally, as mentioned above, we have also explored the impact of the $G O V$ measures in levels only while excluding the interaction term with $F L$. A sample of these results for the global sample is reported in appendix D. Column (1) shows the results obtained when we include all six GOV measures together in the same regression. The remaining columns show the results when each GOV measure is introduced separately in the logit model. While the magnitude of the coefficients differs between the joint $G O V$ and separate $G O V$ estimations, the direction and significance levels remain overall the same for each $G O V$ variable. Overall, the negative coefficients on most $G O V$ variables shown in appendix D confirm the expectation that better banking supervision, stronger law and order tradition, lower corruption and higher government stability help decrease the probability of banking crisis for a given level of financial liberalization. Figure 4 shows the predicted probability of crisis for various levels of financial liberalization and conditional on the governance and institutional measures when ignoring interaction effects between $F L$ and $G O V .{ }^{19}$ The

19. We show the graphs generated using the model with all GOV variables at the same time, but computing marginal effects at each specific $G O V$ in each graph. The same results hold when we plot predicted probabilities based on regressions including one $G O V$ variable at a time. 


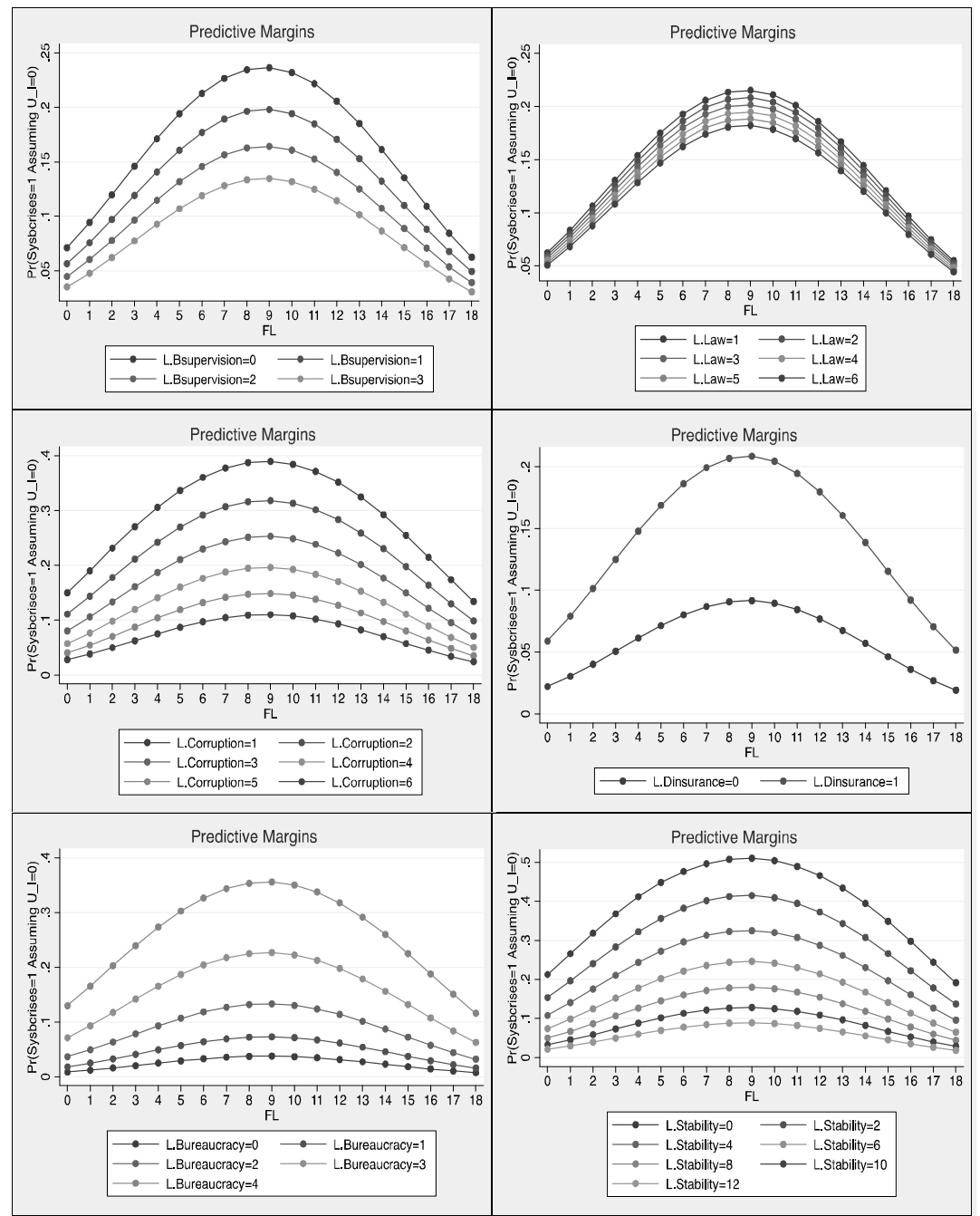

FIGURE 4.- Predicted Probability of Crisis: Model without interaction effects of GOV

Note: This figure shows the predicted probability of systemic banking crisis estimated in a model without interaction effects between $F L$ and $G O V$ (based on the table in appendix D) for different levels of financial liberalization at different levels of governance and institutional quality measures. 


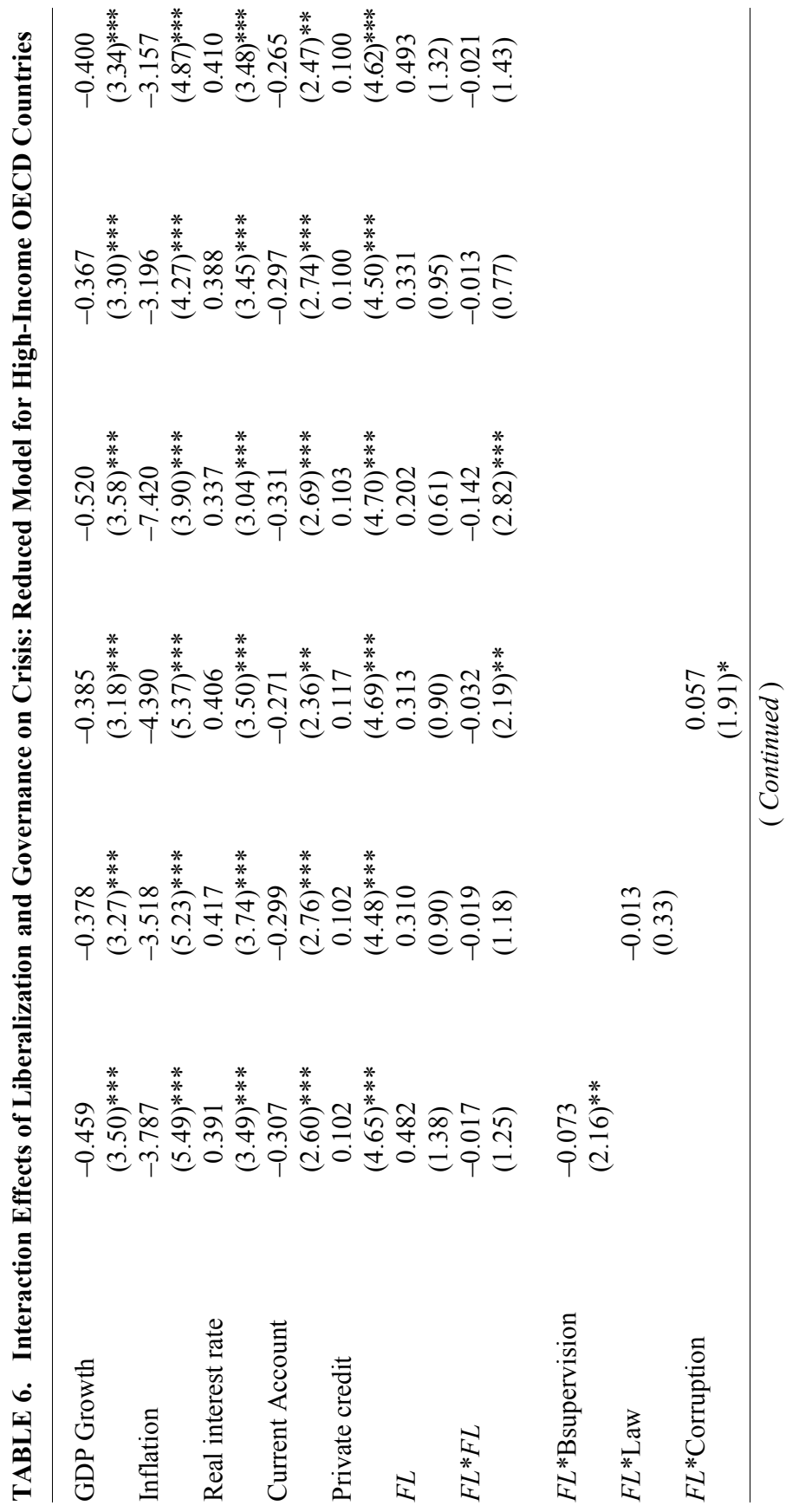




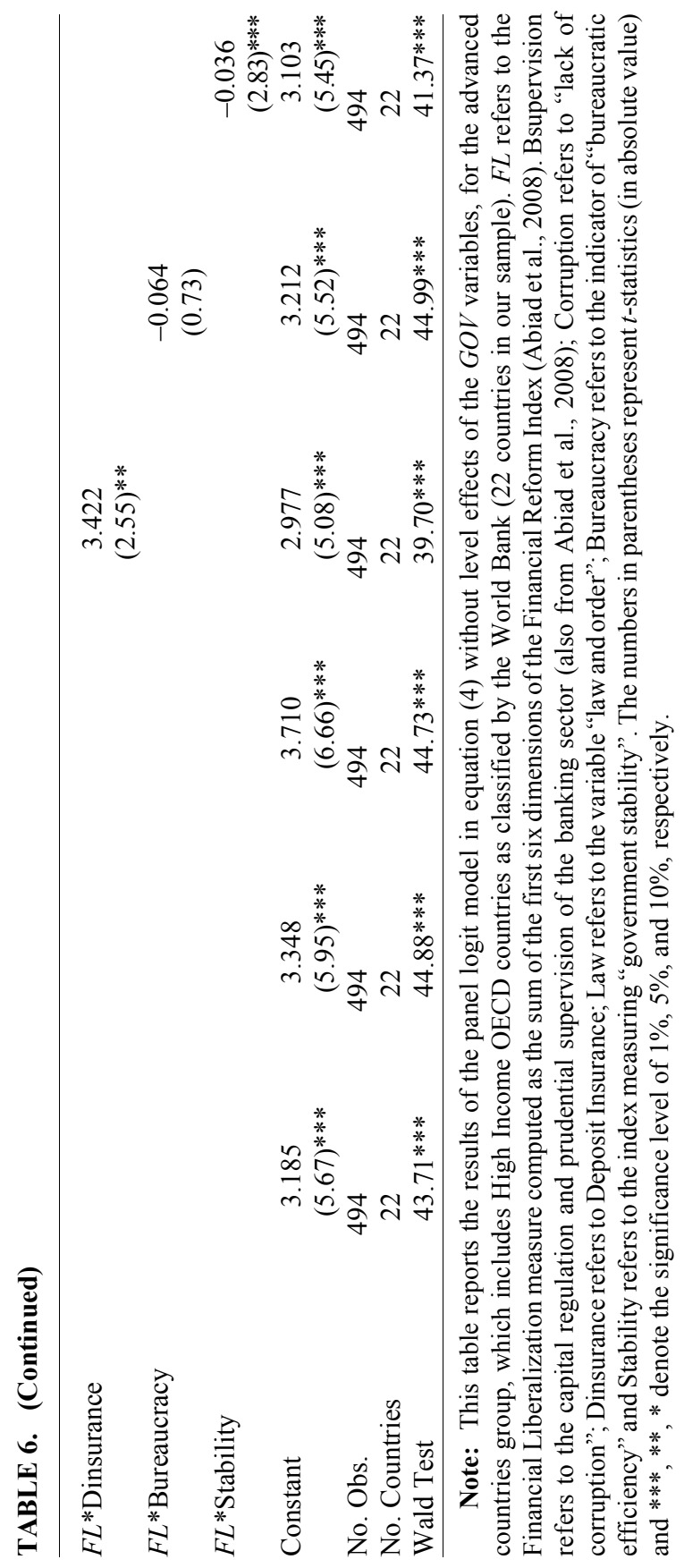




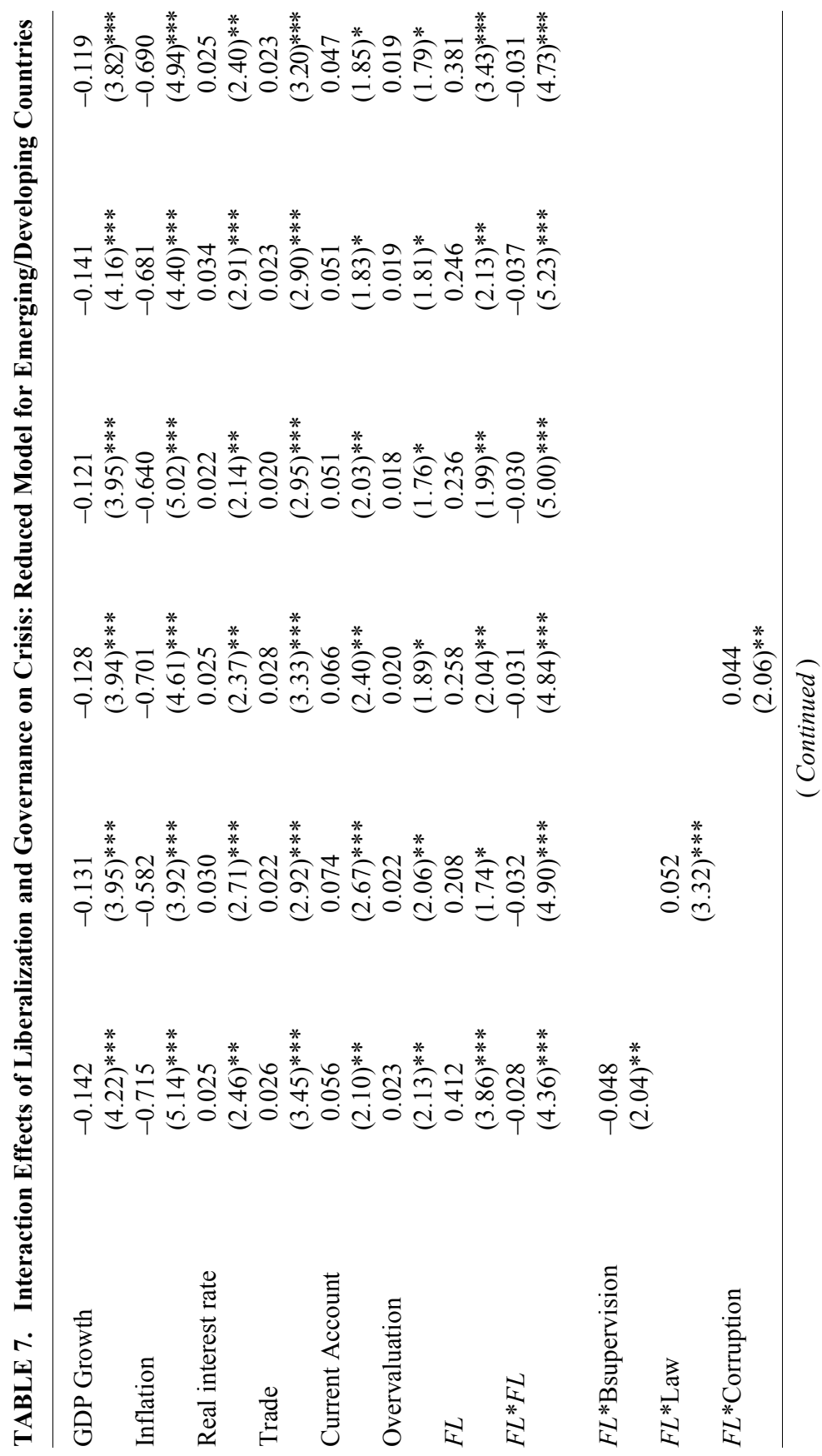




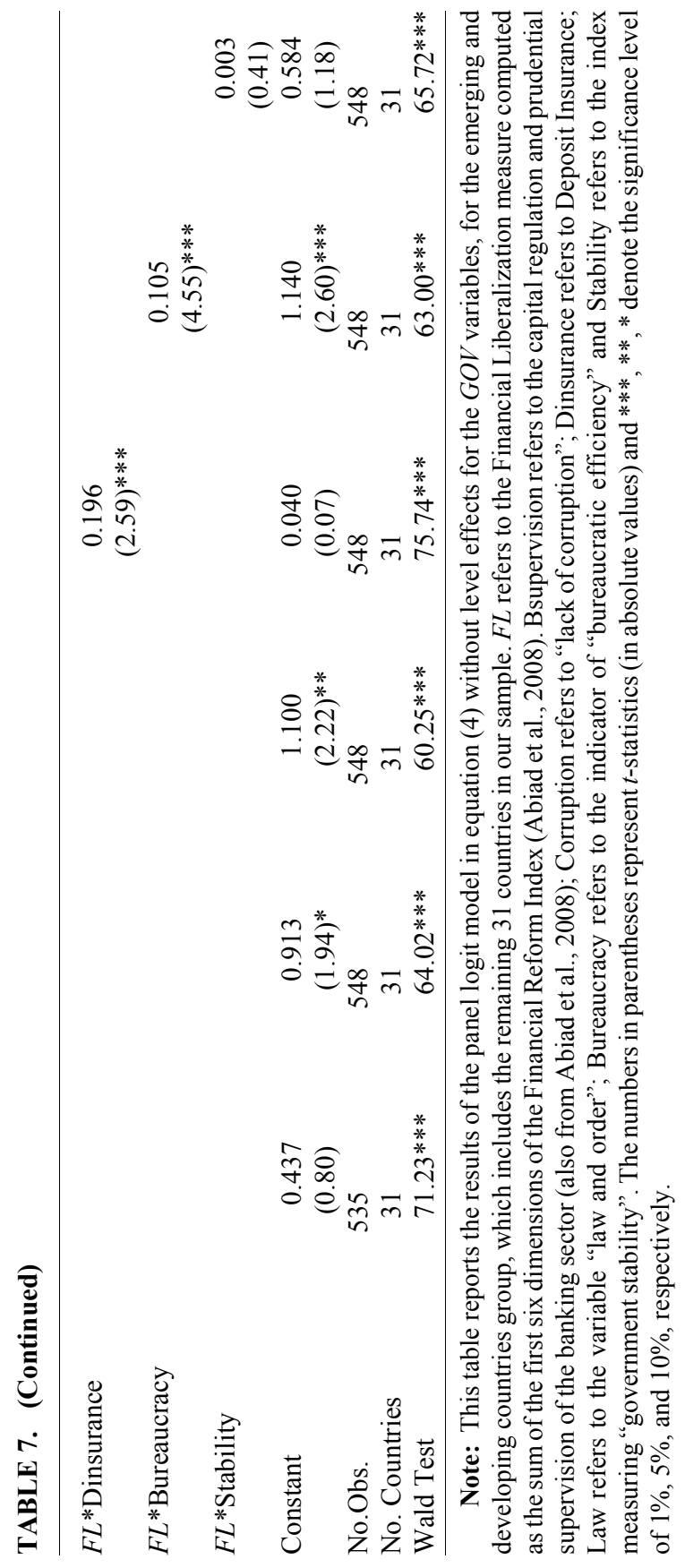


inverted U-shaped relationship between liberalization and crisis appears more strongly in this specification compared with the full model with interaction terms. We can see that the probability of crisis increases with increased liberalization up to a certain intermediate level, at which liberalization starts having a positive effect (lowering the likelihood of crisis). However, overall, and regardless of the level of liberalization, the probability of crisis is always lower with better governance and improved institutional quality (except for the measure of bureaucratic efficiency). The distance between various curves on the same graph can be interpreted as representing the marginal effect of the corresponding $G O V$ variable on the likelihood of crisis for a given level of financial liberalization after controlling for all other determinants of crisis.

\section{Conclusion}

Previous empirical research shows that systemic banking crises are frequent and not restricted to particular geographic regions or levels of economic and financial development. The recent global financial crisis that hit the US and other major economies reminded us that the costs of a systemic banking crisis to an economy (in terms of bailout costs and output losses) could be substantially high with lasting effects on the real sectors. Improving the design of EWSs to detect periods of increased risk of banking crisis is crucial to help governments take timely policy actions to prevent the crisis or limit its negative effects on the economy. Additionally, false alarms about the occurrence of a crisis can be as costly as the failure to detect an upcoming one.

The purpose of this paper is to reexamine the link between financial liberalization and the likelihood of systemic banking crises by taking into account the interaction between financial liberalization and measures of institutional quality and banking governance. While some previous papers included financial liberalization as an explanatory variable of banking crisis and others included limited institutional and governance factors as separate predictors of crises, there are very few studies that examine directly the interaction between the two sets of variables at different levels of financial liberalization and for an extensive set of governance and institutional quality indicators. We take advantage of a more comprehensive liberalization measure, the Financial Reform Index, proposed by Abiad et al. (2008) which captures many dimensions of liberalization enhancing reforms and therefore 
appears more suitable to study the impact of liberalization on the likelihood of crisis and how this relationship may be affected by the quality of the institutional environment at various levels (or stages) of the liberalization process. Such a relevant question is difficult to answer using binary measures of liberalization that only distinguish countries as either fully liberalized or fully repressed without regard to the intermediate stages between the two extreme cases.

We use a multivariate logit model to estimate the probability of systemic banking crisis based on a sample of 53 countries over the period 1980-2005 covering 48 systemic banking crises. In addition to allowing for a non-linear relationship between financial liberalization and crisis, we focus on the interaction effects between liberalization and institutional and governance factors after controlling for the most significant crisis indicators identified in a first step early warning system. We use various institutional variables and governance measures including banking regulation and supervision, deposit insurance, law and order, lack of corruption, bureaucratic efficiency, and government stability.

Our results provide further evidence that there is an inverted U-shaped relationship between financial liberalization and systemic banking crisis that is robust to the country sample and independently from the level of governance and institutional quality measures. This finding is in contrast to earlier crisis literature pointing to liberalization as the main culprit to explain increased likelihood of financial crises. In this paper, we document that this is indeed the case at early stages of liberalization with a predicted probability of crisis reaching peaks at various intermediate levels of liberalization, depending on the countries sample. However, after that, liberalization starts to have a negative relationship with the likelihood of crisis. More specifically, we find that the turning point at which further liberalization starts reducing the likelihood of crisis seems to vary depending on the type of economy (advanced versus emerging/developing). The marginal impact of the governance and institutional quality measures seems to be significant overall, but its magnitude and direction also vary depending on the type of economy and its level of financial liberalization. Further research is needed to determine the types of institutional variables that may be most effective in mitigating the liberalization effect on the likelihood of crisis (or its severity) based on more refined classifications of countries according to more specific characteristics, for example by more disaggregated income levels, or by geographical proximity to account 
for contagion effects.

Our findings have several implications for policy makers concerned about strengthening financial stability and reducing the likelihood of systemic banking crises, particularly in Emerging/Developing countries. First, improving the governance of the banking sector and the quality of institutions can indeed act as a shock absorber following the introduction of liberalization enhancing financial reforms, especially at the earlier stage when liberalization tends to be associated with higher probability of crisis. However, this is not always the case for all governance measures and at all times. The net impact of each governance measure depends on where the country is situated on the liberalization process after controlling for all the relevant determinants of crisis specific to the corresponding type of economy (advanced versus emerging/developing). Second, given the non linear nature of the liberalization-crisis relationship, and the existence of a threshold beyond which liberalization can contribute to reducing the likelihood of crisis, it may be better for some countries to consider introducing various financial reforms simultaneously in order to achieve a higher liberalization degree faster as opposed to a slower and gradual process of financial reform which extends the fragile period during which we tend to see increased likelihood of crisis. Interestingly, the most significant and rapid decline in the likelihood of crisis (as illustrated by the slope of the predicted probability curves after reaching a peak) is sometimes observed in poor governance environments. This suggests a two-way relationship where, at certain levels, the beneficial effect of liberalization weakens the potential negative impact of poor governance environments. Finally, the implication for international policy makers as well as for future academic research on financial crisis prediction, is that it is important to use better measures of financial liberalization and avoid the use of simplistic binary variables of either fully repressed or fully liberalized as most countries are somewhere in between. Further, it may be useful to use more homogeneous country groups that allow for the identification of different sets of explanatory variables for each group when developing global crisis prediction models.

Accepted by: P.C.Andreou, PhD, Editor-in-Chief(Pro-Tem), December 2014 
Appendix A. Episodes of Systemic Banking Crises

\begin{tabular}{|c|c|}
\hline Countries & Dates of systemic banking crises \\
\hline Algeria & $1990-92$ \\
\hline Argentina & (1980-82), (1989-90), 1995, (2001-2003) \\
\hline \multicolumn{2}{|l|}{ Austria } \\
\hline Bangladesh & Late $1980 \mathrm{~s}-96$ \\
\hline \multicolumn{2}{|l|}{ Belgium } \\
\hline Brazil & 1990-(1994-99) \\
\hline \multicolumn{2}{|l|}{ Canada } \\
\hline Chile & $1981-83$ \\
\hline Colombia & $1982-87$ \\
\hline Costa Rica & 1994-96 \\
\hline Cote d'Ivoire & 1988-1992 \\
\hline \multicolumn{2}{|l|}{ Denmark } \\
\hline Dominican Republic & 1991-93 \\
\hline Ecuador & $1982-(1996-2001)$ \\
\hline Egypt & Early $1980 \mathrm{~s}$ \\
\hline El Salvador & 1989 \\
\hline Finland & $1991-94$ \\
\hline \multicolumn{2}{|l|}{ France } \\
\hline \multicolumn{2}{|l|}{ Germany } \\
\hline \multicolumn{2}{|l|}{ Greece } \\
\hline India & 1993 \\
\hline Indonesia & $1997-2002$ \\
\hline \multicolumn{2}{|l|}{ Ireland } \\
\hline \multicolumn{2}{|l|}{ Italy } \\
\hline Jamaica & $1996-2000$ \\
\hline Japan & $1991-2002$ \\
\hline Jordon & 1989 \\
\hline Kenya & (1985-89), (1992-1995) \\
\hline Korea, Rep & $1997-2002$ \\
\hline Malaysia & 1997-2002 \\
\hline Mexico & (1981-91), (1994-97) \\
\hline Morocco & Early 1980 s \\
\hline \multicolumn{2}{|l|}{ Netherlands } \\
\hline \multicolumn{2}{|l|}{ New Zealand } \\
\hline Nigeria & $1991-95$ \\
\hline Norway & 1987-93 \\
\hline \multicolumn{2}{|l|}{ Pakistan } \\
\hline Paraguay & $1995-2000$ \\
\hline Peru & $1983-90$ \\
\hline Philippines & (1981-87), (1998-2002) \\
\hline \multicolumn{2}{|l|}{ Portugal } \\
\hline \multicolumn{2}{|l|}{ South Africa } \\
\hline Spain & $1977-85$ \\
\hline Sri Lanka & 1989-93 \\
\hline
\end{tabular}


Appendix A. (Continued)

\begin{tabular}{ll}
\hline Countries & Dates of systemic banking crises \\
\hline $\begin{array}{l}\text { Sweden } \\
\text { Switzerland } \\
\text { Thailand }\end{array}$ & $1991-94$ \\
Tunisia & $(1983-87),(1997-2002)$ \\
Turkey & $(1982-85),(2000-2002)$ \\
United Kingdom & \\
United States & 1988 \\
Uruguay & $(1981-84), 2002$ \\
Venezuela & $1994-95$ \\
\hline
\end{tabular}

Note: Source: Laeven and Valencia (2012) and Caprio and Klingebiel (2003). Countries included in our "High-Income OECD" sample (22): Austria, Belgium, Canada, Chile, Denmark, Finland, France, Germany, Greece, Ireland, Italy, Japan, Korea, the Netherlands, Norway, New Zealand, Portugal, Spain, Sweden, Switzerland, the United Kingdom, and the United States. Countries included in our "Emerging and Developing countries" sample (31): All other countries from the above table not included in the OECD group. 


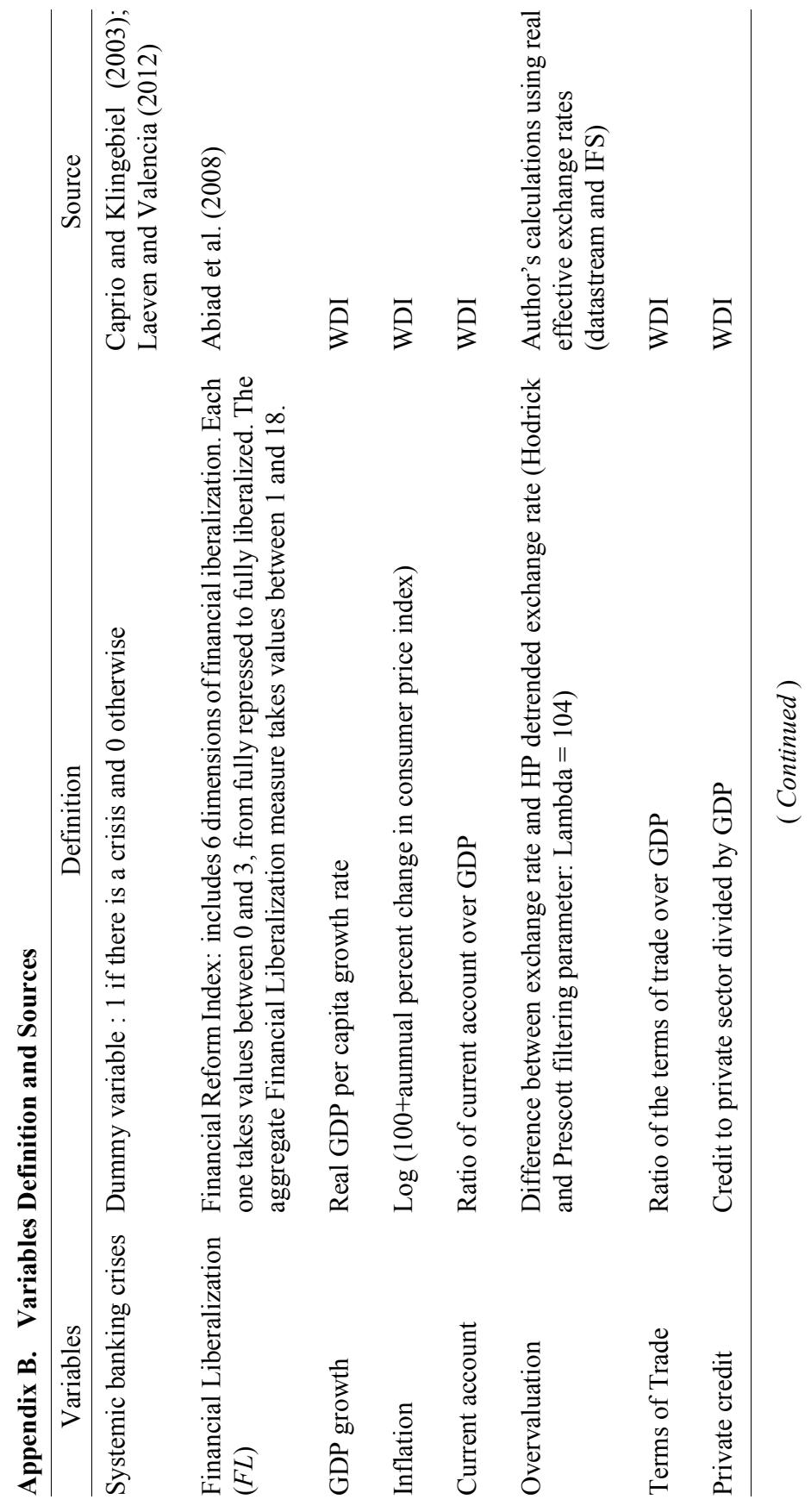




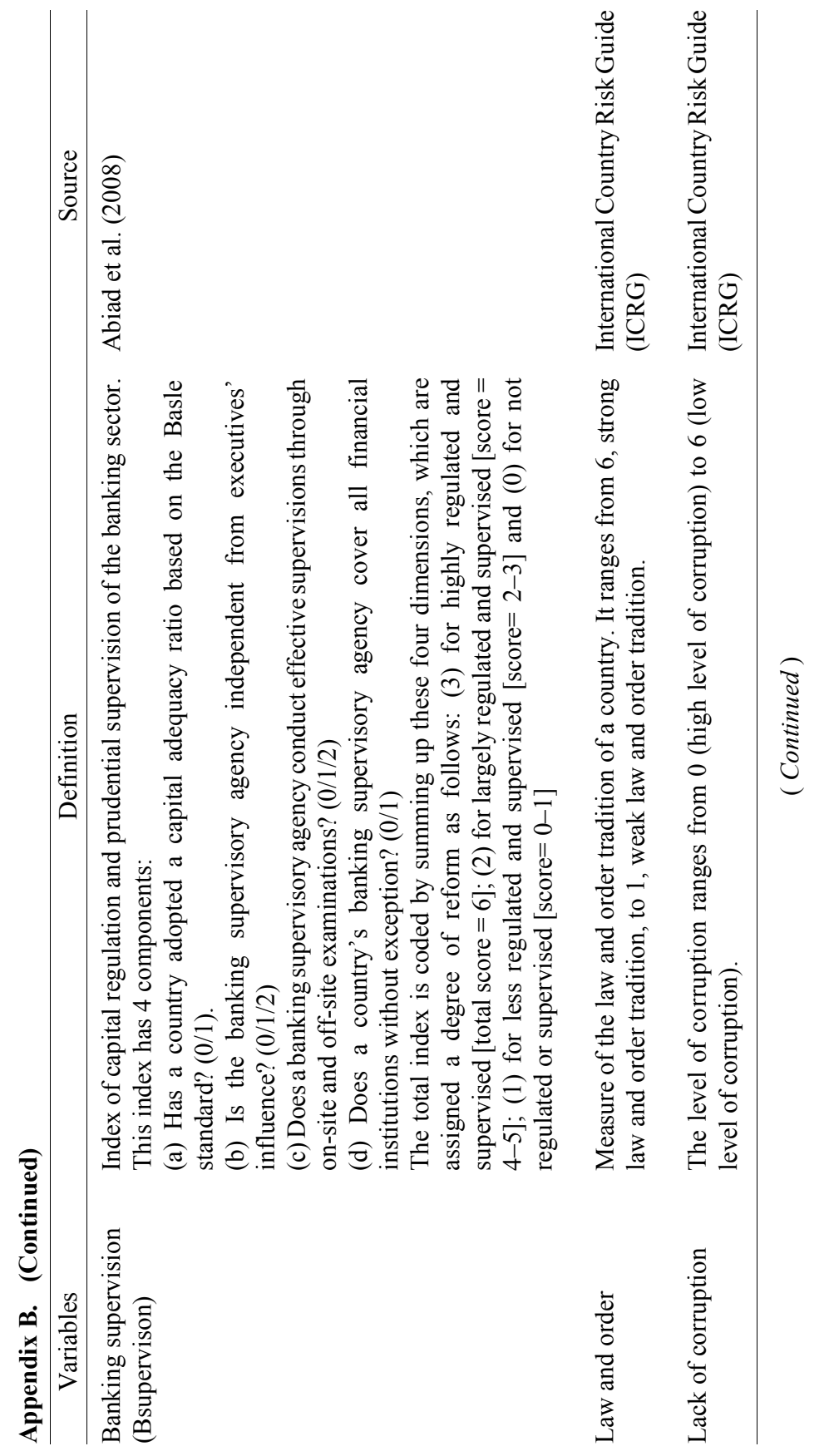




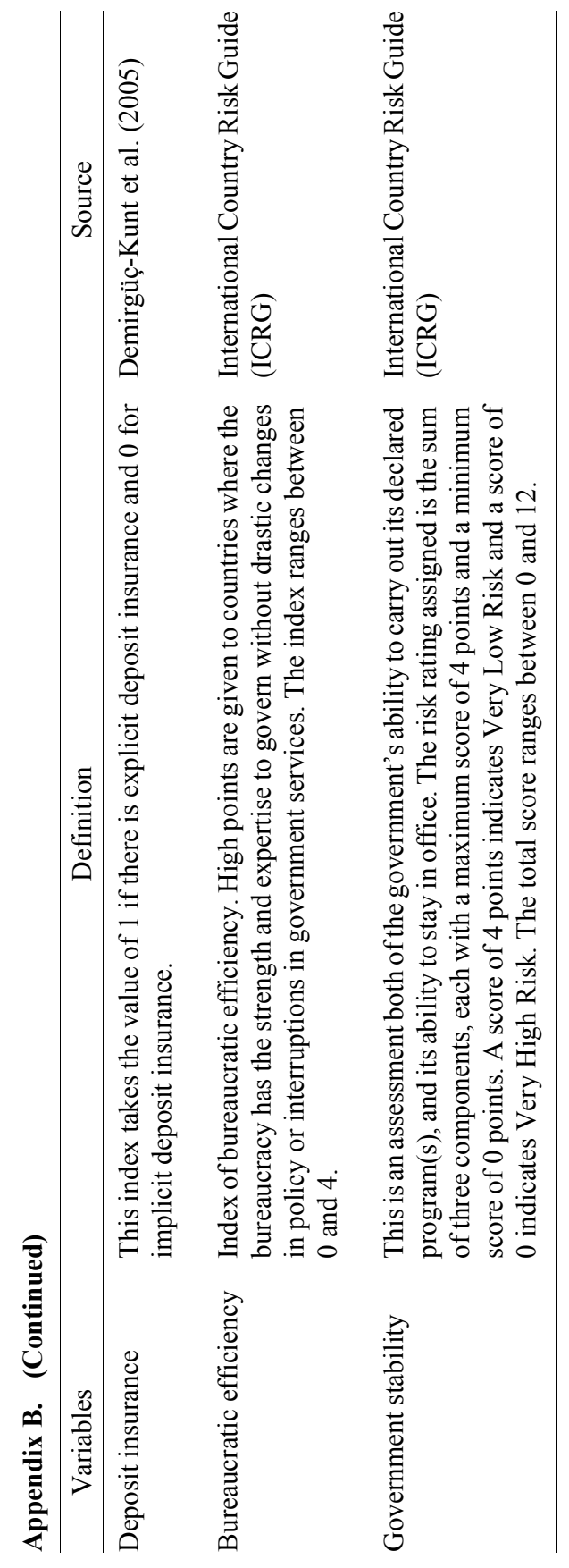


Appendix C. Early Warning Indicators (EWI) of Systemic Banking Crisis

Depend Variable: Systemic Banking Crisis

\begin{tabular}{lccc}
\hline & $\begin{array}{c}\text { All Countries } \\
\text { (Naïve model) }\end{array}$ & $\begin{array}{c}\text { High Income OECD } \\
\text { Countries only }\end{array}$ & $\begin{array}{c}\text { Emerging/Developing } \\
\text { Countries only }\end{array}$ \\
\hline GDP Growth & -0.161 & -0.247 & -0.122 \\
& $(5.31)^{* * *}$ & $(2.10)^{* *}$ & $(4.02)^{* * *}$ \\
Inflation & -2.516 & -2.992 & -2.104 \\
& $(4.11)^{* * *}$ & $(3.09)^{* * *}$ & $(3.53)^{* * *}$ \\
Real Interest Rate & 0.036 & 0.479 & 0.024 \\
& $(3.39)^{* * *}$ & $(3.32)^{* * *}$ & $(2.46)^{* *}$ \\
Terms of Trade & 0.010 & -0.101 & 0.017 \\
& $(1.63)$ & $(1.64)$ & $(2.59)^{* * *}$ \\
Current Account & 0.020 & -0.319 & 0.050 \\
& $(0.81)$ & $(2.26)^{* *}$ & $(2.00)^{* *}$ \\
Overvaluation & 0.008 & -0.033 & 0.021 \\
& $(1.32)$ & $(1.41)$ & $(2.07)^{* *}$ \\
Private Credit & 0.018 & 0.091 & 0.003 \\
& $(3.26)^{* * *}$ & $(3.71)^{* * *}$ & $(0.40)$ \\
Nb. Obs. & 1040 & 494 & 546 \\
Nb. Countries & 53 & 22 & 31 \\
\hline
\end{tabular}

Note: This table reports the results of step one of our methodological approach whereby we estimate the likelihood of systemic banking crisis using standard macroeconomic and financial control variables before including liberalization and governance measures (Panel logit regressions from equation (1) model). All variables are used with one-year lag with respect to the crisis variable. Only statistically significant variables from this step are used in the main model of equation (4) shown in the next tables. All variables and their sources are described in appendix A. The numbers in parentheses represent $t$-statistics (in absolute value). $* * *, * *$, and $*$ denote the significance level at $1 \%, 5 \%$ and $10 \%$, respectively. 


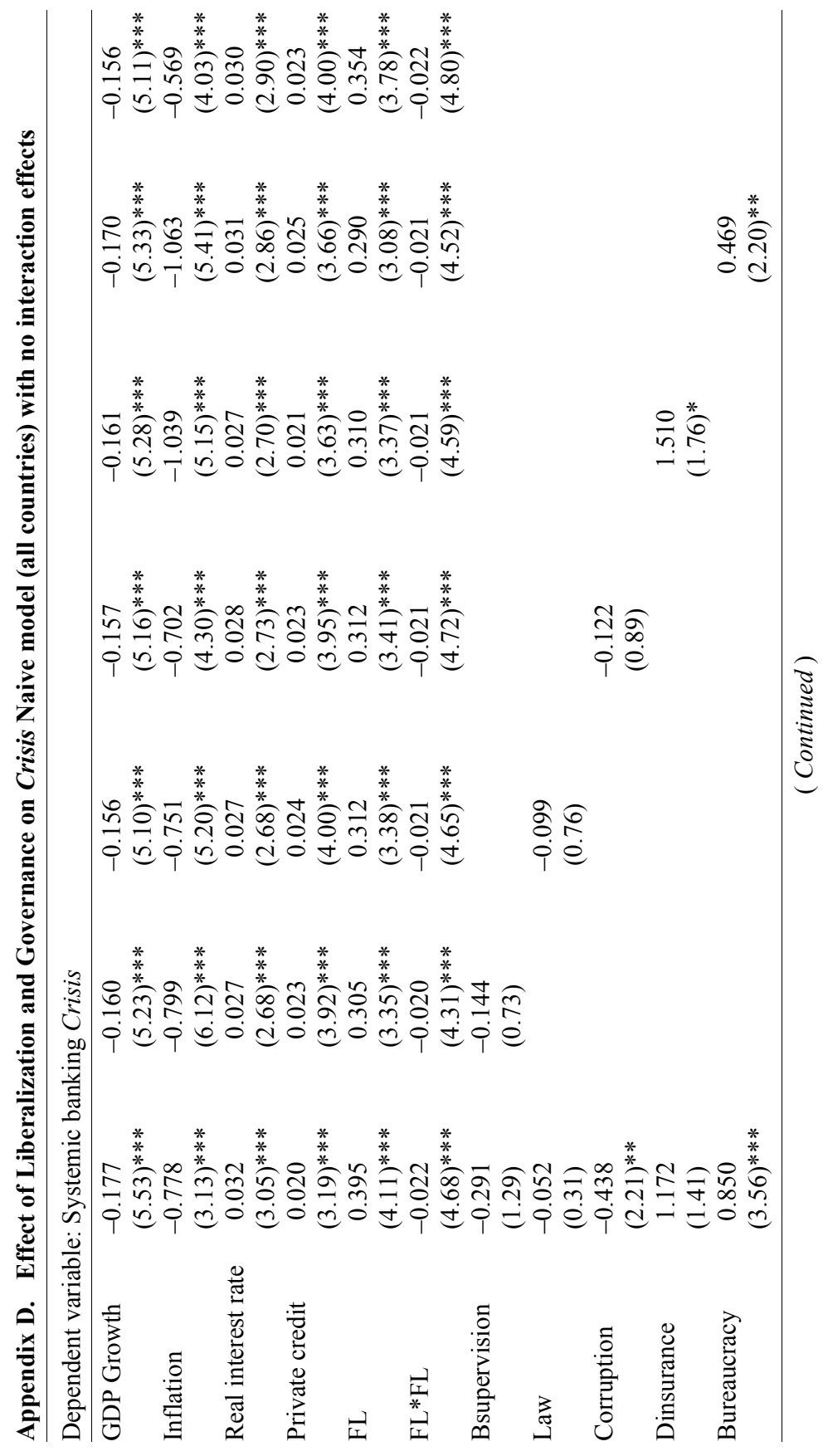




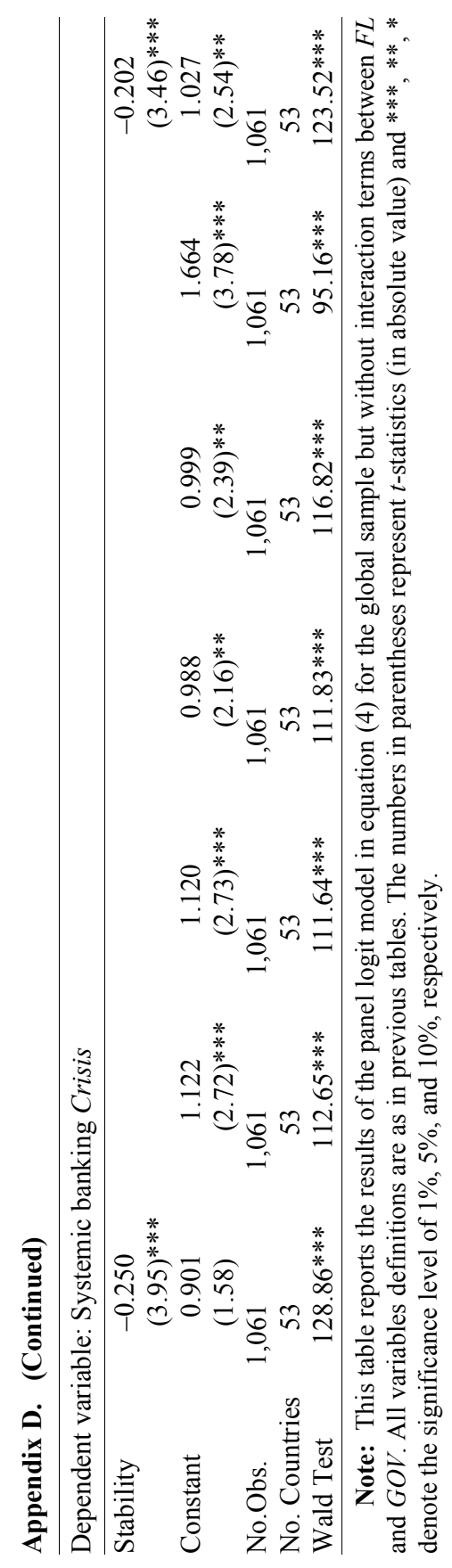




\section{References}

Abiad, A.; Detragiache, E.; and Tressel, T. 2008. A new database of financial reforms. IMF Working Paper, 08/266: 1-30.

Aka, B.E. 2006. On the duration of financial system stability under liberalization. Emerging Markets Review, 7(2):147-161.

Angkinand, A.P. 2009. Banking, regulation and the output cost of banking crises. Journal of International Markets, Institutions and Money, 19(2): 240-257.

Angkinand, A.; Barth, Jr.R.; Phumiwasana, T.; and Wihlborg, C. 2006. Regulatory and market forces in controlling bank risk-taking: a cross-country analysis. AIB Southeast Asia Regional Conference, Bangkok, Thailand.

Angkinand, A.P.; Sawangngoenyuang, W.; and Wihlborg, C. 2010. Financial 1 liberalization and banking crises: A Cross-Country Analysis. International Review of Finance, 10 (2): 263-292.

Arnone, M.; Darbar, S.M.; and Gambini, A. 2007. Banking supervision: Quality and governance. IMF Working Paper, 07/82: 1- 32.

Barrell, R.; Davis, E. P.; Karim, D.; and Liadze, I. 2010. Bank regulation, property prices and early warning systems for banking crises in OECD countries, Journal of Banking and Finance, 34(9): 2255-2264.

Barth, J.R.; Caprio, Jr.G.; and Levine, R. 2004. Bank regulation and supervision: What works best?. Journal of Financial Intermediation, 13(2): 205-248

Beck, T.; Demirgúç-Kunt, E.; and Levine, R. 2006. Bank supervision and corruption in lending. Journal of Monetary Economics, 53(8): 2131-2163

Bekaert, G.; Harvey, C.R.; and Lundblad, C. 2005. Does financial liberalization spur growth?. Journal of Financial Economics, 77(1): 3-55.

Berg, J.V.; Candelon, B.; and Urbain, J.P. 2008. A cautious note on the use of panel models to predict financial crises. Economics Letters, 101(1): 80-83.

Caprio, G., and Klingebiel, D. 2003. Episodes of systemic and borderline financial crises, World Bank.

Caprio, G., and Klingebiel, D. 1996. Bank insolvency: bad luck, bad policy or bad banking?. World Bank Conference on Development Economics, 1-29.

Currie, C. 2006. A new theory of financial regulation: Predicting, measuring and preventing financial crises. The Journal of Socio-Economics, 35(1): 48-71.

Daniel, B.C., and Jones, J.B. 2007. Financial liberalization and banking crises in emerging economies. Journal of International Economics, 72(1): 202-221.

Davis, E.P., and Karim, D. 2008. Comparing early warning systems for banking crises. Journal of Financial Stability, 4(2): 89-120.

Dekle, R., and Kletzer, K. 2001. Domestic bank regulation and financial crises: Theory and empirical evidence from East Asia. NBER Working Papers, $\mathrm{N}^{\circ} 8322$.

Demirguc-Kunt, A.; Karacovali, B.; and Laeven, L. 2005. Deposit insurance around the world: Comprehensive database. World Bank Policy Research, WP N $\mathrm{N}^{\mathrm{O}} .3628$. 
Demirgüç-Kunt, A., and Detragiache, E. 1998. Financial liberalization and financial fragility. N.1917. World Bank Publications.

Demirgüç-Kunt, A., and Detragiache, E. 2005. Cross-country empirical studies of systemic bank distress: a survey. National Institute Economic Review 192: 68-83.

Diaz-Alejandro, C. 1985. Good-Bye financial repression, hello financial crash. Journal of Development Economics, 19(1-2): 1-24.

Eichengreen, B., and Arteta, C. 2002. Banking crises in emerging markets: presumption and evidence. Financial Policies in Emerging Markets, 47-94.

Eichengreen, B., and Rose, A.K. 1998. Staying afloat when the wind shifts: External factors and emerging-market banking crises. NBER Working Papers, $\mathrm{N}^{\circ} 6370,1-48$.

Giannetti, M. 2007. Financial liberalization and banking crises: The role of capital inflows and lack of transparency. Journal of Financial Intermediation, 16(1): 32-63.

Glick, R., and Hutchison, M. 2001. Banking and currency crises: How common are twins? In: R. Glick, R., Moreno, M. Spiegel (eds), Financial crises in emerging markets. Cambridge, UK: Cambridge University Press, 35-69.

Gupta, R., and Karapatakis, A.G. 2008. Financial liberalization: A myth or a miracle cure?. Journal of Monetary Economics, 6: 6-33.

Hellman, T.; Murdock, K.; and Stiglitz, J. 2000. Liberalization, moral hazard in banking, and prudential regulation: are capital requirements enough?. American Economic Review, 90: 147-165.

Kaminsky, G.L., and Reinhart, C. 1999. The twin: the causes of banking and balance of payments problems. American Economic Review, 89(3): 473-500.

Kaminsky, G.L., and Schmukler, S.L. 2008. Short-run pain, long-run gain: financial liberalization and stock market cycles. Review of Finance, 12: 253-292.

Karim, D. 2008. The use of binary recursive trees for banking crisis prediction. Brunel University, Mimeo.

Laeven, L., and Valencia, F. 2008. Systemic banking crises: A new database. International Monetary Fund.

Mehrez, G., and Kaufman, D. 2000. Transparency, liberalization and banking crisis. World Bank Policy Research, WP N²286, 1-40.

Neumann, R.M.; Penl, R.; and Tanku, A. 2009. Volatility of capital flows and financial liberalization: Do specific Flows respond differently?. International Review of Economics and Finance, 18(3):488-501.

Noy, I. 2004. Financial liberalization, prudential supervision, and the onset of banking crises. Emerging Markets Review, 5(3):341-359.

Ranciere, R.; Tornell, A.; and Westermann, F. 2006. Decomposing the effects of financial liberalization: crises versus growth. Journal of Banking and Finance, 30 (12):3331-3348.

Shehzad, C.T., and De Haan J. 2009. Financial Reform and Banking Crises, CESIFO Working Paper. N 2870.

Tornell, A.; Westermann, F.; and Martinez, L. 2004. The positive link between financial liberalization, growth and crises. NBER Working Papers, $\mathrm{N}^{\circ} 10293$. 